\title{
Calcium promotes cadmium elimination as vaterite grains by tobacco trichomes
}

\author{
Marie-Pierre Isaure $^{\mathrm{a}, *}$, Géraldine Sarret ${ }^{\mathrm{a}}$, Emiko Harada ${ }^{\mathrm{a}, \mathrm{c}, \mathrm{d}, 1}$, Yong-Eui Choi ${ }^{\mathrm{c}}$, \\ Matthew A. Marcus ${ }^{\text {, }}$, Sirine C. Fakra ${ }^{b}$, Nicolas Geoffroy ${ }^{\text {a,2 }}$, Sébastien Pairis ${ }^{\text {e, }}$ \\ Jean Susini ${ }^{\text {f }}$, Stephan Clemens ${ }^{\mathrm{d}, 3}$, Alain Manceau ${ }^{\mathrm{a}}$ \\ ${ }^{a}$ Institut des Sciences de la Terre (ISTerre) Université Joseph Fourier and CNRS, BP 53, 38041 Grenoble cedex 9, France \\ ${ }^{\mathrm{b}}$ Advanced Light Source (ALS), Lawrence Berkeley National Lab, MS 6-100, Berkeley, CA 94720, USA \\ ${ }^{\mathrm{c}}$ Division of Forest Resources, College of Forest and Environmental Sciences, Kangwon National University, Chunchon 200-701, \\ Kangwon-do, South Korea \\ ${ }^{\mathrm{d}}$ Leibniz-Institut für Pflanzenbiochemie, 06120 Halle, Saale, Germany \\ ${ }^{\mathrm{e}}$ Institut Néel, Université Joseph Fourier and CNRS, Dept. Matière Condensée, Matériaux et Fonctions, \\ Pôle Instrumentation (Microscopie Electronique), BP 166, 38042 Grenoble cedex 9, France \\ ${ }^{\mathrm{f}}$ European Synchrotron Radiation Facility (ESRF), BP 220, 38043 Grenoble cedex, France
}

\begin{abstract}
In tobacco plants, elimination of $\mathrm{Zn}$ and $\mathrm{Cd}$ via the production of $\mathrm{Ca}$-containing grains at the top of leaf hairs, called trichomes, is a potent detoxification mechanism. This study examines how $\mathrm{Cd}$ is incorporated in these biominerals, and how calcium growth supplement modifies their nature. Scanning electron microscopy coupled with energy dispersive X-ray microanalysis (SEM-EDX), microfocused X-ray diffraction ( $\mu$-XRD), and microfocused X-ray absorption near edge structure ( $\mu$-XANES) spectroscopy were used to image the morphology of the grains, identify the crystallized mineral phases, and speciate $\mathrm{Cd}$, respectively. The mineralogy of the grains and chemical form of $\mathrm{Cd}$ varied with the amount of $\mathrm{Ca}$. When tobacco plants were grown in a nutrient solution containing $25 \mu \mathrm{M} \mathrm{Cd}$ and low $\mathrm{Ca}$ supplement $(\mathrm{Ca} / \mathrm{Cd}=11 \mathrm{~mol}$ ratio $)$, most of the grains were oblong-shaped and low-Cd-substituted calcite. When exposed to the same amount of Cd and high Ca supplement $(\mathrm{Ca} / \mathrm{Cd}=131 \mathrm{~mol}$ ratio), grains were more abundant and diverse in compositions, and in total more Cd was eliminated. Most grains in the high $\mathrm{Ca} / \mathrm{Cd}$ experiment were round-shaped and composed predominantly of Cd-substituted vaterite, a usually metastable calcium carbonate polymorph, and subordinate calcite. Calcium oxalate and a $\mathrm{Ca}$ amorphous phase were detected occasionally in the two treatments, but were devoid of $\mathrm{Cd}$. The biomineralization of cadmium and implications of results for $\mathrm{Cd}$ exposure of smokers and phytoremediation are discussed.
\end{abstract}

(C) 2010 Elsevier Ltd. All rights reserved.

\footnotetext{
* Corresponding author. Present address: Marie-Pierre Isaure, Institut Pluridisciplinaire de Recherche sur l'Environnement et les Matériaux/Laboratoire de Chimie Analytique Bio-Inorganique et Environnement (IPREM-UMR 5254/LCABIE), Université de Pau et des Pays de l'Adour, Hélioparc, 2 Avenue Pierre Angot, 64053 PAU Cedex 9 France. Tel.: +33 540175053.

E-mail address: marie-pierre.isaure@univ-pau.fr (M.-P. Isaure).

1 Present address: Research Institute for Sustainable Humanosphere (RISH), Kyoto University Gokasho, Uji 611-0011 Kyoto Japan.

2 Present address: Laboratoire Interdisciplinaire Carnot de Bourgogne UMR 5209 CNRS and Université de Bourgogne, BP 47870, 21078 Dijon cedex, France.

${ }^{3}$ Present address: Department of Plant Physiology, University of Bayreuth, Universitaetsstrasse 30, D-95440 Bayreuth, Germany.
} 


\section{INTRODUCTION}

Plants have developed various defence strategies against toxic heavy metals, including complexation and chelation with strong ligands, and compartmentation into specific tissues, cells and cellular organelles (Clemens, 2006). Accumulation of metals inside trichomes, specialized cells located at the surface of leaves, is common and was documented, for example, in Brassica juncea L. (Salt et al., 1995), Alyssum lesbiacum (Krämer et al., 1997), Cucurbita moschata (Iwasaki and Matsumura, 1999), Nymphaea sp. (Lavid et al., 2001), and Arabidopsis halleri and thaliana (Küpper et al., 2000; Zhao et al., 2000; Sarret et al., 2002; 2009; Isaure et al., 2006). Heavy metals can also be excreted at the top of this hair-like appendage, but this process is less common and generally observed in halophyte species, such as Armeria maritima ssp. (Neumann et al., 1995), Silene vulgaris (Bringezu et al., 1999), Avicennia marina, (MacFarlane and Burchett, 1999) and Atriplex halimus L. (Lefèvre et al., 2009). Tobacco (Nicotiana tabacum L. cv. Xanthi) detoxifies $\mathrm{Zn}$ and $\mathrm{Cd}$ by producing micrometer-sized $\mathrm{Ca} /$ $\mathrm{Zn}$ and $\mathrm{Ca} / \mathrm{Cd}$-containing grains at the top of trichomes, similarly to halophytes (Choi et al., 2001; 2004; Choi and Harada, 2005; Sarret et al., 2006; 2007).

Biomineralization processes can be biologically induced or biologically controlled (Lowenstam, 1981). In the first case, the living organism modifies the physico-chemical conditions of its environment, so as to induce mineral precipitation near or at its surface. The organism has little control over the type and shape of minerals, which generally have heterogeneous morphology, composition, and structure. In biologically controlled biomineralization, nucleation, crystal growth, and the shape and size of crystallites can be controlled by biomolecules (Webb, 1999; Franceschi and Nakata, 2005).

The production of grain precipitated by tobacco plants is considered to be biologically induced, but the formation mechanism remains unclear (Sarret et al., 2006; 2007). The $\mathrm{Ca} / \mathrm{Zn}$ grains produced under $\mathrm{Zn}$ and $\mathrm{Zn}+\mathrm{Ca}$ exposures were $20-150 \mu \mathrm{m}$ in diameter and polycrystalline aggregates of submicrometer crystals with some amorphous material. The crystals were composed dominantly of ( $\mathrm{Zn}, \mathrm{Mg}, \mathrm{Mn}$ )substituted calcite. Aragonite and vaterite, the two other $\mathrm{CaCO}_{3}$ polymorphs, amorphous $\mathrm{CaCO}_{3}$ and $\mathrm{Ca}$ oxalate $\left(\mathrm{CaC}_{2} \mathrm{O}_{4}\right)$ monohydrate (whewellite) and dihydrate (weddellite) secondarily occurred, generally as an admixture of calcite. Other possible species included $\mathrm{Zn}$ complexed to organic compounds, $\mathrm{Zn}$-containing silica and $\mathrm{Zn}$ phosphate. The proportion of $\mathrm{Zn}$-substituted calcite relative to other $\mathrm{Zn}$ species and the density of trichomes increased with $\mathrm{Ca}$, and in total more $\mathrm{Zn}$ was excreted.

As with $\mathrm{Zn}$, trichomes produced $10-150 \mu \mathrm{m} \mathrm{Ca} / \mathrm{Cd}$ grains when the plant roots were in contact with cadmium (Choi et al., 2001; 2004; Choi and Harada, 2005). Cd exposure retarded tobacco growth and doubled the density of trichomes per unit leaf area. Tolerance to metal toxicity was enhanced by adding $\mathrm{Ca}$, which stimulated the production of grains (Choi et al., 2001). Because Cd and Ca form complete solid solutions in carbonates, as a result of their oxidation state and similar ionic radii $(0.95$ and $1.00 \AA$, respectively; Reeder, 1983), tolerance to Cd toxicity is probably linked to the production of calcium carbonate, but in a form and a manner as yet unknown. In this study, the nature of the $\mathrm{Cd}$ precipitates was investigated by growing tobacco plants in hydroponics in the presence of low and high Ca concentrations. The morphology, chemical composition, and crystalline nature of the $\mathrm{Ca} / \mathrm{Cd}$ grains, and $\mathrm{Cd}$ speciation were characterized using scanning electron microscopy coupled with energy dispersive X-ray microanalysis (SEM-EDX), microfocused X-ray diffraction ( $\mu$ $\mathrm{XRD}$ ), and microfocused $\mathrm{Cd} \mathrm{L}_{\mathrm{III}}$-edge X-ray absorption near edge structure ( $\mu$-XANES) spectroscopy. The Cd species were identified by principal component analysis (PCA), and their proportions in grains quantified by linear leastsquares combination fit (LSF) of the $\mu$-XANES spectra.

\section{MATERIALS AND METHODS}

\subsection{Plant cultures and isolation of grains from tobacco}

Tobacco (Nicotiana tabacum L. cv. Xanthi) seeds were germinated on solid medium-filled PCR tubes, and transferred after three weeks to $1.5 \mathrm{~L}$ pots (three plants per pot) filled with one-tenth-strength Hoagland medium. To prevent insect attack and dust contamination, plants were grown at $22{ }^{\circ} \mathrm{C}$ in a closed culture box in a growth chamber with $16 \mathrm{~h}$-light $/ 8 \mathrm{~h}$-dark cycle. After three weeks, plants were transferred to a medium containing $25 \mu \mathrm{M} \mathrm{CdCl} 2 \cdot 2 \mathrm{H}_{2} \mathrm{O}$ and $0.28 \mathrm{mM} \mathrm{Ca}(\mathrm{Cd}$ treatment $)$ or $3.28 \mathrm{mM} \mathrm{Ca}(\mathrm{Cd}+\mathrm{Ca}$ treatment). The treatment lasted 5 weeks. An experiment with $3.28 \mathrm{mM} \mathrm{Ca}$ only (Ca treatment) was performed for control, as described in Sarret et al. (2006). Grains were collected by plunging and vortexing plants in $50 \mathrm{~mL}$ tubes containing deionized water for a few seconds. The supernatant was carefully and quickly removed, and the grains at the bottom were collected with a pipette and dried in vacuum (Speed Vac SC100, Savant Instruments). The grains dissolve within 2 min at $\mathrm{pH} 2$, within 10 min at $\mathrm{pH} 3$ and are sparingly soluble from $\mathrm{pH} 4$ to 12.5 (Sarret et al., 2006). Thus, water extraction did not modify the initial grain's structure and composition.

\subsection{Cd references}

Solid and aqueous Cd-containing standards were prepared and analyzed by $\mathrm{Cd} \mathrm{L}_{\mathrm{III}}$-edge XANES spectroscopy. Synthesis of Cd-phosphate $\left(\mathrm{Cd}_{5} \mathrm{H}_{2}\left(\mathrm{PO}_{4}\right)_{4} \cdot 4\left(\mathrm{H}_{2} \mathrm{O}\right)\right)$ and Cd-oxalate $\left(\mathrm{CdC}_{2} \mathrm{O}_{4}\right)$, and the preparation of $\mathrm{Cd}^{2+}{ }_{\text {aq }}$ and $\mathrm{Cd}$ organic compounds, including Cd-pectin, Cd-citrate, Cd-malate, $\mathrm{Cd}$-cell wall ( $\mathrm{Cd}$ adsorbed on cell walls extracted from tobacco roots), and Cd-cysteine, were described previously (Isaure et al., 2006). Commercial powders of CdS, $\mathrm{CdSO}_{4}, \mathrm{CdCl}_{2}$, and $\mathrm{CdCO}_{3}$ (otavite) were purchased from Sigma-Aldrich, and their purity and crystallinity verified by XRD. In addition, Cd-containing calcite and vaterite were synthesized at room temperature by a protocol modified from Paquette and Reeder (1995) and Reeder (1996). Solid ammonium carbonate was introduced into a $50-\mathrm{mL}$ Falcon tube floating in a sealed glass reactor containing $500 \mathrm{~mL}$ of $10 \mathrm{mM} \mathrm{CaCl}_{2}$ and $1.8 \mathrm{M} \mathrm{NH}_{4} \mathrm{Cl}$. The second salt was used as a background electrolyte to provide a high 
ionic strength. Initial $\mathrm{pH}$ was 4.9. The gradual decomposition of ammonium carbonate produced $\mathrm{NH}_{3(\mathrm{~g})}$ and $\mathrm{CO}_{2(\mathrm{~g})}$, which dissolved into the solution, increasing $\mathrm{pH}$ and alkalinity. The supersaturation of the unstirred solution led to the nucleation and growth of $\mathrm{CaCO}_{3}$ crystals. Continuous sublimation of $\mathrm{NH}_{3(\mathrm{~g})}$ buffered the solution near $\mathrm{pH}$ 7.9.

After 13 days, the reactor contained rhombohedral crystals of calcite and spherical particles of vaterite attached to the surface of the glass. At this time, the $\mathrm{CaCl}_{2}-\mathrm{NH}_{4} \mathrm{Cl}$ solution was spiked slowly for 7 days with $0.1 \mathrm{M} \mathrm{CdCl}_{2}$ to a total concentration of $100 \mu \mathrm{M} \mathrm{Cd}$ or $10 \mu \mathrm{M} \mathrm{Cd}$. During this period, crystals continued to grow and $\mathrm{Cd}$ was incorporated as a $\mathrm{Ca}$ substituent in vaterite (Cd100-vaterite and $\mathrm{Cd} 10$-vaterite) and calcite (Cd100-calcite and Cd10-calcite). The gradual addition of $\mathrm{CdCl}_{2}$ maintained the solution undersaturated with respect to otavite. Because $\mathrm{Mg}$ occurs in all grains produced by tobacco (Choi et al., 2001; 2004), (Cd, Mg)-substituted calcite ((Cd100, Mg100)-calcite) and (Cd, Mg)substituted vaterite ((Cd100, Mg100)-vaterite) also were synthesized by co-adding $100 \mu \mathrm{M} \mathrm{CdCl}_{2}$ and $100 \mu \mathrm{M} \mathrm{MgCl}_{2}$ to a $\mathrm{CaCl}_{2}-\mathrm{NH}_{4} \mathrm{Cl}$ solution after 13 days and for 7 days. After 20 days, the particles from the three experiments were collected, rinsed with deionized water, and handpicked on the basis of their morphology. The distribution in size $(150-200 \mu \mathrm{m})$ was independent of the morphology. SEMEDX, XRD and microfocused X-ray fluorescence ( $\mu$-XRF) analyses showed that the rhombohedral crystals were pure Cd-containing or $(\mathrm{Cd}, \mathrm{Mg})$-containing calcite, and the spherical particles pure $\mathrm{Cd}$-containing or $(\mathrm{Cd}, \mathrm{Mg})$-containing vaterite. Several tens of calcite and vaterite grains from the $100 \mu \mathrm{M} \mathrm{Cd}$ experiments were digested at $200{ }^{\circ} \mathrm{C}$ with pure $\mathrm{HCl}$ in Teflon bombs, and $\mathrm{Cd}$ concentrations analyzed by inductively coupled plasma atomic emission spectrometry (ICP-AES). The Cd10-calcite and Cd10-vaterite crystals could not be analyzed by ICP-AES due to the limited supply of material.

Cd-sorbed calcite was prepared following the protocol described in Elzinga and Reeder (2002). Briefly, $0.1 \mathrm{~g}$ of powdered calcite (Fluka) was controlled by XRD and equilibrated at ambient pressure and temperature in $1 \mathrm{~L}$ ultrapure water for 1 month. The suspension stabilized at $\mathrm{pH}$ 8.2 was spiked with $2 \mu \mathrm{mol} \mathrm{Cd}$ from a $0.01 \mathrm{M} \mathrm{CdCl}_{2}$ solution. The $\mathrm{pH}$ remained constant for the 2 days of equilibration, at which time the suspension was filtered, and the solid rinsed and dried for XANES measurements.

\subsection{SEM-EDX analyses}

Grains from tobacco and references were stuck on carbon stubs with carbon or kapton tape, coated with carbon, and examined with a Jeol-JSM 840A scanning electron microscope running at $20 \mathrm{keV}$ and equipped with a Kevex $\mathrm{Si}(\mathrm{Li})$ diode EDX system. The chamber pressure was $10^{-6}$ to $10^{-5}$ Torr. Elemental concentrations were obtained by applying ZAF corrections (IDFix software).

\section{4. $\mu$-XRF, $\mu$-XRD and $\mu$-XANES data collection}

The $\mu$-XRF, $\mu$-XRD, and some of the $\mu$-XANES measurements were performed on beamline 10.3.2 at the Ad- vanced Light Source (ALS) of the Lawrence Berkeley National Laboratory (Marcus et al., 2004). The tobacco grains were mounted on kapton tape (DuPont) and cooled to $150 \mathrm{~K}$ at ambient pressure with an Oxford Cryostream 611 cooler to minimize any potential beam damage during measurements. Cd-rich spots were localized by $\mu-\mathrm{XRF}$ at an incident X-ray energy of $3550 \mathrm{eV}$ (i.e., below $\mathrm{Ca}$ $\mathrm{K}$-edge), and their $\mu$-XRD patterns recorded with a $1024 \times 1024$ pixels Bruker Smart 6000 CCD camera at an incident energy of $17 \mathrm{keV}$ and a beam size of 16 $(\mathrm{H}) \times 7(\mathrm{~V}) \mu \mathrm{m}^{2}$. Cd L $\mathrm{L}_{\mathrm{III}}$-edge $\mu$-XANES spectra were collected in fluorescence-yield detection mode on Cd-richest spots with a Canberra seven-element germanium detector and a beam size of $7 \times 7 \mu \mathrm{m}^{2}$. Because $\mathrm{Cd}$ and $\mathrm{Ar}$ (from air) fluorescence emission lines overlap, $\mu$-XRF and $\mathrm{Cd}$ $\mathrm{L}_{\mathrm{III}}$-edge $\mu$-XANES measurements of the low-Cd samples were carried out in vacuum $\left(10^{-7}-10^{-8}\right.$ Torr $)$ on the spectromicroscopy beamline ID-21 at the European Synchrotron Radiation Facility (ESRF, Grenoble) using a one-element solid-state high purity germanium detector (Princeton Gamma Tech, Princeton, USA). Measurements on ID-21 were performed at room temperature and a beam size of $0.70(\mathrm{H}) \times 0.35(\mathrm{~V}) \mu \mathrm{m}^{2}$. The Cd L L $\mathrm{L}_{\mathrm{III}}$-edge $\mu$ XANES spectra are averages of 3-20 successive scans collected on different spots.

\section{5. $\mu$-XRD and $\mu$-XANES data analysis}

The two-dimensional XRD patterns were calibrated with alumina $\left(\mathrm{Al}_{2} \mathrm{O}_{3}\right)$ and integrated to one-dimensional patterns using fit2D software (Hammersley et al., 1996). The stoichiometry of the Mg-, Mn-, Zn-, and Cd-substituents in calcite crystals was estimated by refining the unit cell parameters $a$ and $c$ over the $10-33^{\circ} 2 \theta$ angular range (1.3$4.0 \AA$ interval at $17 \mathrm{keV}$ ) using the Ufit software (Evain, 1992), and applying the Vegard law (West, 1984). The end-members for Vegard law calculations were calcite, magnesite $\left(\mathrm{MgCO}_{3}\right)$, rhodocrosite $\left(\mathrm{MnCO}_{3}\right)$, smithsonite $\left(\mathrm{ZnCO}_{3}\right)$, and otavite $\left(\mathrm{CdCO}_{3}\right)$. The unit cell parameters $a$ and $c$ of the substituted vaterite crystals were refined but the stoichiometry of the substituents could not be estimated, because of the lack of metal carbonates isomorphic to vaterite.

The $\mu$-XANES spectra were calibrated using the first inflection point of $\mathrm{Cd}$ metal set at $3538 \mathrm{eV}$, then pre-edge background subtracted with a linear polynomial and postedge normalized with a linear or quadratic polynomial using the Athena software (Ravel and Newville, 2005). The normalized spectra were analyzed by principal components analysis (PCA; Ressler et al., 2000) using the beamline 10.3.2 LabView based software (Manceau et al., 2002). This numerical linear algebra analysis allows estimating the number of species required to describe the dataset, provided the number of species is smaller than the number of spectra and their fractional amounts vary in the dataset, and identifying their nature from a library of model compounds by target transformation. The number of principal components (i.e. Cd species) was evaluated with the IND local minimum criterion, and the quality of the reconstruction of the reference spectra by 
target transformation with the SPOIL value $(S)$ and the normalized sum-squared residual $N S S=[\Sigma$ (Normalized Absorption $_{\text {th }}-$ Normalized Absorption $\left._{\text {exp }}\right)^{2} / \Sigma$ (Normalized Absorption $\left.\left._{\text {exp }}\right)^{2}\right] \times 100$ in the $3530-3585 \mathrm{eV}$ range (Malinowski, 1977, 1978; Manceau et al., 2002). Then, the proportions of $\mathrm{Cd}$ species in the multi-component XANES spectra were obtained by least-squares fitting (LSF) of the grain spectra to linear combinations of reference spectra previously identified by PCA. The quality of the fits was quantified with NSS. Visual examination of all individual fits showed that the grains contained at most two major species; the addition of a second component being justified when NSS decreased by at least $40 \%$. Spectra were checked for possible over-absorption as de- scribed in Sarret et al. (2007) using the beamline 10.3.2 LSF LabView based software, and this effect was not observed.

\section{RESULTS}

\subsection{Morphology and chemical composition of the grains}

\subsubsection{Abiotic grains}

The vaterite grains were all spherical and the calcite grains rhombohedral (Fig. 1a and b). The concentration of $\mathrm{Cd}$ in $\mathrm{Cd} 100$-calcite was heterogeneous within each grain and between grains, with $\mathrm{Cd}$ contents varying from 1 to $60 \mathrm{mg} \mathrm{g}^{-1} \mathrm{Cd}$, as estimated by EDX. Cadmium was below
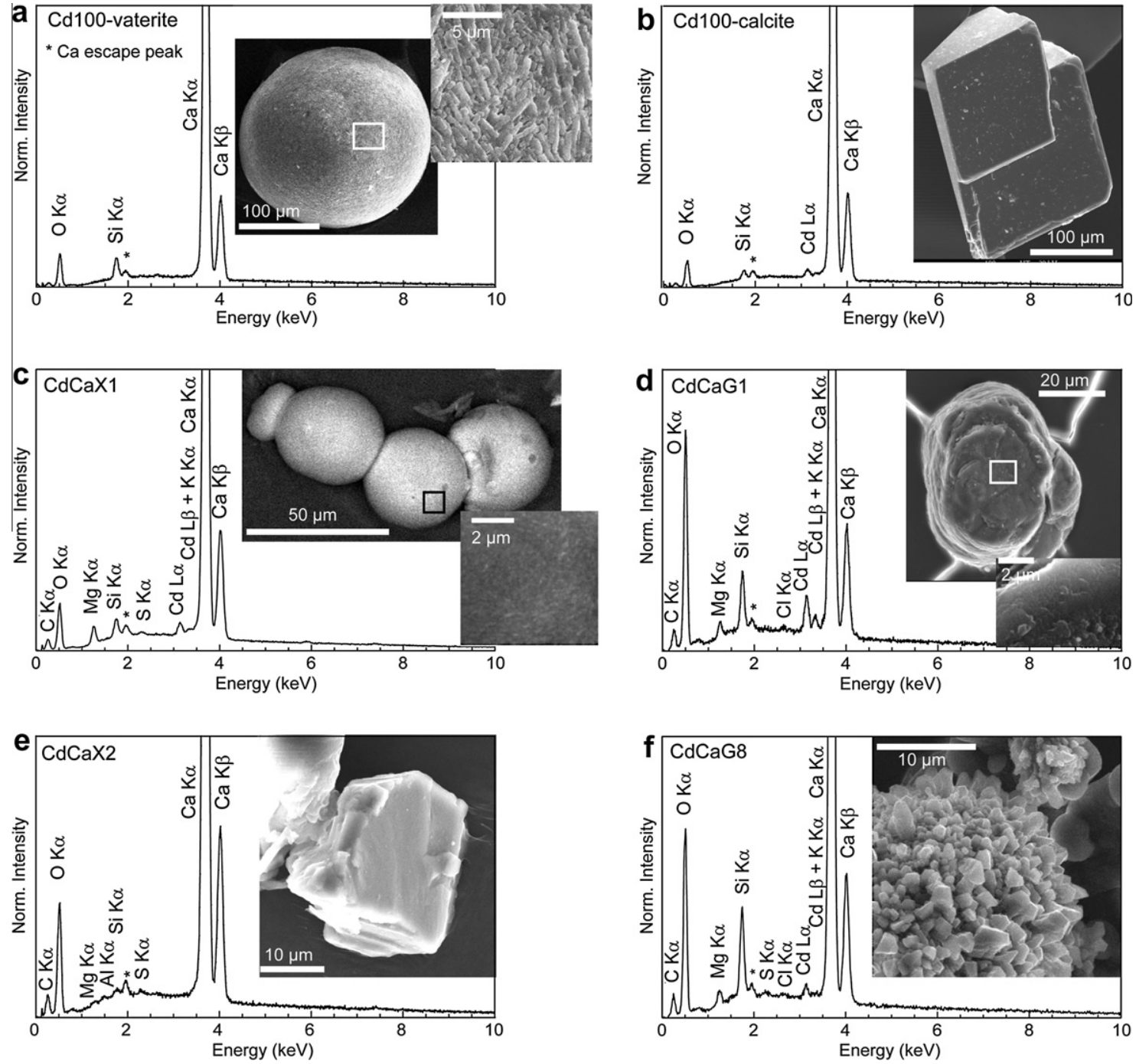

Fig. 1. SEM images and EDX spectra of calcium carbonate grains. (a and b) synthetic Cd-substituted vaterite and calcite. c-j) Biogenic grains produced by tobacco plants grown hydroponically for five weeks in the presence of $3 \mathrm{mM} \mathrm{Ca}+25 \mu \mathrm{M} \mathrm{Cd}(\mathrm{Cd}+\mathrm{Ca}$ treatment, c-f), or $0.28 \mathrm{mM} \mathrm{Ca}+25 \mu \mathrm{M} \mathrm{Cd}(\mathrm{Cd}$ treatment, g-j). $\mathrm{CdCaX} 1(\mathrm{c})$ and $\mathrm{CdCaG} 1(\mathrm{~d})$ are spherical and globular grains rich in vaterite, and $\mathrm{CdCaX} 2(\mathrm{e})$ and $\mathrm{CdCaG} 8$ (f) are calcitic grains from the $\mathrm{Cd}+\mathrm{Ca}$ treatment. CdG1 (g), CdG2 (h), and CdG3 (i) are representative oblong calcitic grains from the $\mathrm{Cd}$ treatment. CdG12 (j) is a unique hemispherical vaterite-rich grain from the $\mathrm{Cd}$ treatment. The two grains named $\mathrm{CdCaX}$ were examined only by SEM-EDX, and the other grains also by diffraction and XANES spectroscopy. Cadmium was always detected in nonfaceted vaterite-rich grains, and occasionally in faceted calcitic grains from the $\mathrm{Cd}+\mathrm{Ca}$ treatment. In contrast, $\mathrm{Cd}$ was never detected in the oblong calcitic grains from the $\mathrm{Cd}$ treatment. 

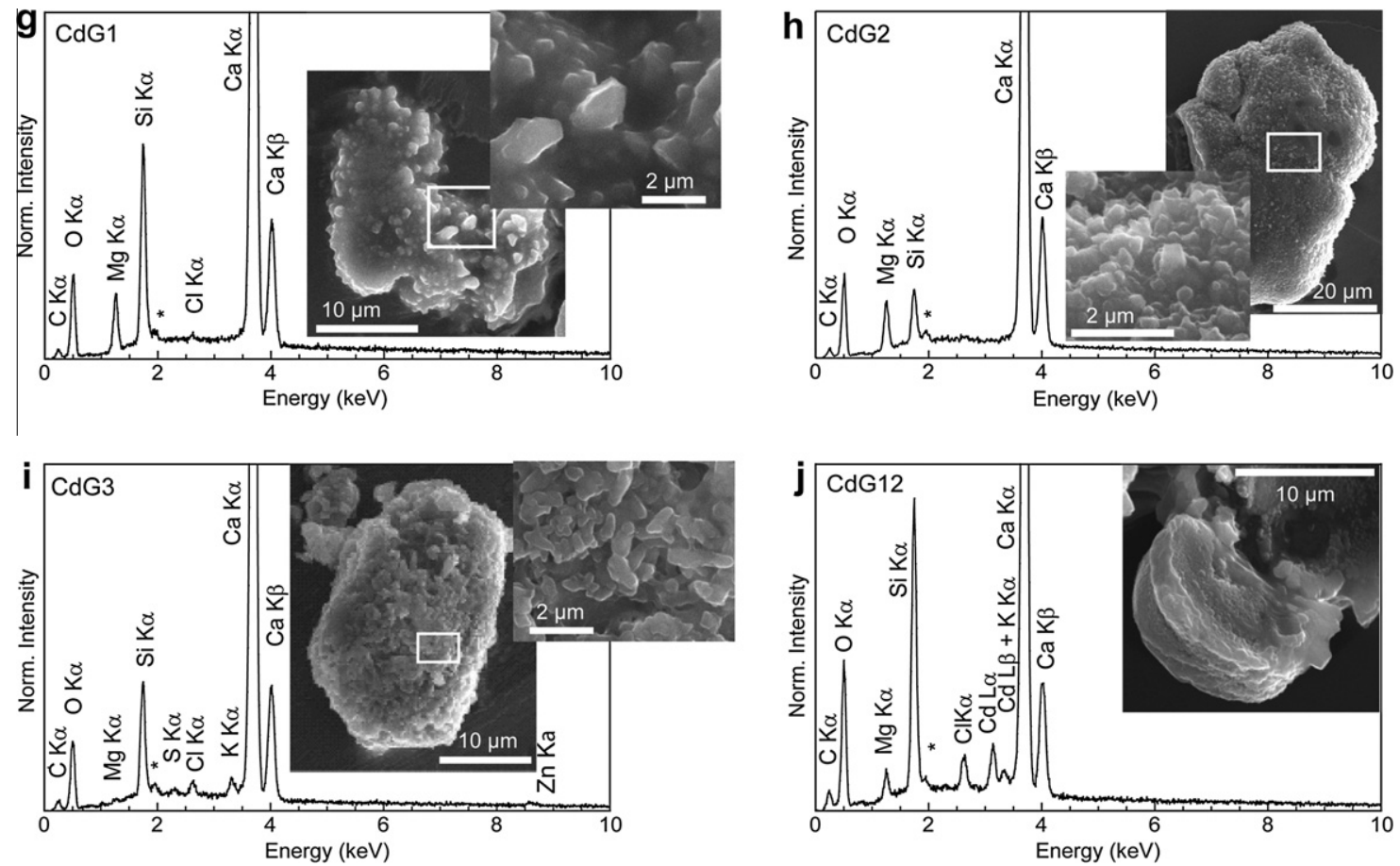

Fig. 1 (continued)

the detection limit of EDX in Cd100-vaterite, but was detected by $\mu$-XRF. The average $\mathrm{Cd}$ contents obtained by ICP-AES were $1.8 \mathrm{mg} \mathrm{g}^{-1}$ for Cd100-calcite and $54 \mu \mathrm{g} \mathrm{g}^{-1}$ for Cd100-vaterite. From $\mu$-XRF analysis, Cd10-vaterite contained less $\mathrm{Cd}$ than Cd10-calcite, and (Cd100, Mg100)vaterite less than (Cd100, Mg100)-calcite. Magnesium decreased the amount of $\mathrm{Cd}$ incorporated in both calcite and vaterite.

\subsection{2. $\mathrm{Cd}+\mathrm{Ca}$ treatment}

About twenty grains were examined. Their size ranged from 20 to $150 \mu \mathrm{m}$, and approximately $75 \%$ were rounded to sub-rounded and composed of minute $(<1 \mu \mathrm{m})$ particles, suggesting the predominance of vaterite (Fig. 1c and d). From EDX analysis, they all contained $\mathrm{Ca}, \mathrm{Mg}$, and $\mathrm{Cd}$. The Cd concentration varied from 9 to $55 \mathrm{mg} \mathrm{g}^{-1}$ with a mean value of approximately $29 \mathrm{mg} \mathrm{g}^{-1}$. About $20 \%$ of the grains contained faceted calcite-like crystals. Some did not contain $\mathrm{Cd}$ in contrast to the rounded grains, and the mean concentration of these faceted $\mathrm{Cd}$ grains was $17 \mathrm{mg} \mathrm{g}^{-1}$ (Fig. 1e and f). Thus, Cd seems to have a higher affinity for biogenic vaterite than for calcite. The reverse trend was observed for the inorganic Cd100-calcite and Cd100-vaterite references: $\mathrm{Cd}$ was more abundant in calcite than in vaterite grains. Minor $\mathrm{Al}, \mathrm{S}, \mathrm{Cl}$, and $\mathrm{K}$ were detected regardless of morphologies. The other grains appeared amorphous; $\mathrm{Ca}$ was still the major element present, but $\mathrm{Cd}$ was never detected (results not shown). An intense $\mathrm{Si} \mathrm{K} \alpha$ peak was observed when grains were mounted on Kapton, but not on carbon tape (e.g., grains $\mathrm{CdCaG8}$, Fig. 1f). This peak is likely an artifact coming from a secondary excitation of Kapton by the $\mathrm{Ca} \mathrm{K} \alpha$ fluorescence emitted by the grains.

\subsubsection{Cd treatment}

The grain size varied between 20 and $150 \mu \mathrm{m}$ and the grain shape oblong, except for three grains out of approximately 20 grains examined, which were rounded. The oblong grains were composed of micrometer (Fig. 1g) to submicrometer (Fig. $1 \mathrm{~h}$ and i) crystals and had no detectable $\mathrm{Cd}$. Neither calcite nor vaterite could be recognized from the grain or crystal morphologies. One hemispherical grain was analyzed by EDX (CdG12), and found to contain Cd (Fig. 1j).

\subsubsection{Ca treatment}

Most grains were composed of faceted calcite-like crystals, and contained $\mathrm{Mg}$ and occasionally $\mathrm{Mn}$ impurities, as described in Sarret et al. (2006).

\subsection{Mineralogy of the grains}

\subsection{1. $C d+C a$ treatment}

Twelve grains were examined by $\mu$-XRD (Table 1). $\mathrm{CdCaG} 1$ is representative of the most frequently observed rounded grains ( $\mathrm{CdCaG} 1$ to $\mathrm{CdCaG} 7)$. The intensities of the Debye rings are not constant along the ring perimeters, and are characteristic of submicrometer crystals with preferred orientations (Fig. 2a) (Manceau et al., 2002). The texture looks like several lumps of mosaic crystals squashed together, as further discussed below regarding the stability of calcium carbonates. The XRD peaks are from vaterite only, but shifted to higher wavevector $Q$ values (i.e. smaller $d$ values) relative to pure vaterite (Fig. 2c). The contraction of the unit cell from $a=7.148 \AA$ and $c=16.949 \AA$ in vaterite to $a=7.06 \pm 0.01 \AA$ and $c=16.72 \pm 0.01 \AA$ in $\mathrm{CdCaG} 1$ likely results from the substitution of $\mathrm{Mg}$ (ionic radius 
Table 1

Micro-XRD results.

\begin{tabular}{lllll}
\hline Carbonate minerals & \multicolumn{2}{l}{ Unit cell parameters } & $\begin{array}{c}\text { Ionic radius for divalent cations } r(\AA) \\
\text { (Shannon, 1976) }\end{array}$ \\
\cline { 2 - 5 } & $a(\AA)$ & $c(\AA)$ & References & 1.00 \\
\hline Calcite $\left(\mathrm{CaCO}_{3}\right)$ & 4.9896 & 17.0610 & Effenberger et al. (1981) & 0.95 \\
Otavite $\left(\mathrm{CdCO}_{3}\right)$ & 4.923 & 16.287 & Borodin et al. (1979) & 0.83 \\
Rhodocrosite $\left(\mathrm{MnCO}_{3}\right)$ & 4.7682 & 15.6354 & Effenberger et al. (1981) & 0.74 \\
Smithsonite $\left(\mathrm{ZnCO}_{3}\right)$ & 4.6526 & 15.0257 & - & 0.72 \\
Magnesite $\left(\mathrm{MgCO}_{3}\right)$ & 4.6328 & 15.0129 & - & Meyer $(1969)$
\end{tabular}

\begin{tabular}{|c|c|c|c|c|c|c|c|c|c|c|c|}
\hline \multirow[t]{2}{*}{ Grains } & \multicolumn{2}{|c|}{$\begin{array}{l}\text { Unit cell } \\
\text { parameters }\end{array}$} & \multirow[t]{2}{*}{ Mineralogy } & \multicolumn{4}{|c|}{$\begin{array}{l}\text { Average amounts of metal } \\
\text { substituents in calcite } \\
\text { calculated from the } a \\
\text { parameter }\end{array}$} & \multicolumn{4}{|c|}{$\begin{array}{l}\text { Average amounts of } \\
\text { metal substituents in } \\
\text { calcite calculated from } \\
\text { the } c \text { parameter } \mathrm{Mg}\end{array}$} \\
\hline & $a(\AA)$ & $c(\AA)$ & & $\mathrm{Mg}$ & $\mathrm{Zn}$ & $\mathrm{Mn}$ & $\mathrm{Cd}$ & $\mathrm{Mg}$ & $\mathrm{Zn}$ & Mn & $\mathrm{Cd}$ \\
\hline \multicolumn{12}{|c|}{ Grains from the $\mathrm{Cd}+\mathrm{Ca}$ treatment } \\
\hline CdCaG1 & 7.06 & 16.72 & Substituted vaterite & & & & & & & & \\
\hline $\mathrm{CdCaG} 2$ & 7.07 & 16.72 & Substituted vaterite & & & & & & & & \\
\hline $\mathrm{CdCaG} 3$ & 7.08 & 16.78 & Substituted vaterite & & & & & & & & \\
\hline $\mathrm{CdCaG} 4$ & 7.07 & 16.79 & Substituted vaterite $+\mathrm{W}(\mathrm{t})$ & & & & & & & & \\
\hline $\mathrm{CdCaG} 5$ & 7.09 & 16.81 & Substituted vaterite $+\mathrm{W}(\mathrm{t})$ & & & & & & & & \\
\hline CdCaG6 & 7.08 & 16.79 & Substituted vaterite + substituted calcite $(\mathrm{t})+\mathrm{W}(\mathrm{t})$ & & & & & & & & \\
\hline $\mathrm{CdCaG} 7$ & 7.06 & 16.70 & Substituted vaterite + substituted calcite $(\mathrm{t})$ & & & & & & & & \\
\hline $\mathrm{CdCaG} 8$ & 4.91 & 16.79 & Substituted calcite & 0.22 & 0.24 & 0.36 & $1.00^{\mathrm{a}}$ & 0.13 & 0.13 & 0.19 & 0.35 \\
\hline $\mathrm{CdCaG} 9$ & 4.92 & 16.83 & Substituted calcite & 0.19 & 0.21 & 0.31 & $1.00^{\mathrm{a}}$ & 0.11 & 0.11 & 0.16 & 0.30 \\
\hline \multirow[t]{2}{*}{ CdCaG10 } & 4.93 & 16.72 & Substituted calcite + substituted vaterite & 0.17 & 0.18 & 0.27 & 0.89 & 0.17 & 0.18 & 0.24 & 0.44 \\
\hline & 7.07 & 16.75 & & & & & & & & & \\
\hline \multirow[t]{2}{*}{ CdCaG11 } & 4.93 & 16.89 & Substituted calcite + substituted vaterite & 0.17 & 0.18 & 0.27 & 0.89 & 0.09 & 0.09 & 0.13 & 0.23 \\
\hline & 7.09 & 16.69 & & & & & & & & & \\
\hline CdCaG12 & & & No $\mu$-XRD peaks & & & & & & & & \\
\hline \multicolumn{12}{|c|}{ Grains from the Cd treatment } \\
\hline CdG1 & 4.90 & 16.52 & Substituted calcite $+\mathrm{W}(\mathrm{t})$ & 0.25 & 0.27 & 0.40 & $1.00^{\mathrm{a}}$ & 0.26 & 0.26 & 0.38 & 0.70 \\
\hline $\mathrm{CdG} 2$ & 4.91 & 16.55 & Substituted calcite $+\mathrm{W}(\mathrm{t})$ & 0.22 & 0.24 & 0.36 & $1.00^{\mathrm{a}}$ & 0.25 & 0.25 & 0.36 & 0.66 \\
\hline $\mathrm{CdG} 3$ & 4.96 & 16.93 & Substituted calcite & 0.08 & 0.09 & - & 0.44 & 0.06 & 0.06 & - & 0.17 \\
\hline CdG4 & 4.92 & 16.45 & Substituted calcite + A & 0.19 & 0.21 & 0.31 & $1.00^{\mathrm{a}}$ & 0.30 & 0.30 & 0.43 & 0.79 \\
\hline CdG5 & 4.88 & 16.50 & Substituted calcite & 0.31 & 0.32 & 0.49 & $1.00^{\mathrm{a}}$ & 0.27 & 0.27 & 0.39 & 0.72 \\
\hline CdG6 & 4.89 & 16.50 & Substituted calcite & 0.28 & 0.30 & 0.45 & $1.00^{\mathrm{a}}$ & 0.27 & 0.27 & 0.39 & 0.72 \\
\hline CdG7 & 4.87 & 16.55 & Substituted calcite $+\mathrm{W}+\mathrm{A}(\mathrm{t})$ & 0.33 & 0.35 & 0.54 & $1.00^{\mathrm{a}}$ & 0.25 & 0.25 & 0.36 & 0.66 \\
\hline CdG8 & 4.91 & 16.59 & Substituted calcite $+\mathrm{W}(\mathrm{t})$ & 0.22 & 0.24 & 0.36 & $1.00^{\mathrm{a}}$ & 0.23 & 0.23 & 0.33 & 0.61 \\
\hline CdG9 & 4.91 & 16.65 & Substituted calcite & 0.22 & 0.24 & 0.36 & $1.00^{\mathrm{a}}$ & 0.20 & 0.20 & 0.29 & 0.53 \\
\hline CdG10 & 4.88 & 16.65 & Substituted calcite & 0.31 & 0.32 & 0.49 & $1.00^{\mathrm{a}}$ & 0.20 & 0.20 & 0.29 & 0.53 \\
\hline CdG11 & 4.96 & 16.93 & Substituted calcite $+\mathrm{W}(\mathrm{t})$ & 0.08 & 0.09 & - & 0.44 & 0.06 & 0.06 & - & 0.17 \\
\hline \multirow{2}{*}{ CdG12 } & 4.90 & 16.71 & Substituted calcite + substituted vaterite $+\mathrm{W}$ & 0.25 & 0.27 & 0.40 & $1.00^{\mathrm{a}}$ & 0.17 & 0.17 & 0.25 & 0.45 \\
\hline & 7.08 & 16.75 & & & & & & & & & \\
\hline CdG13 & & & No $\mu$-XRD peaks & & & & & & & & \\
\hline CdG14 & & & No $\mu$-XRD peaks & & & & & & & & \\
\hline CdG15 & & & No $\mu$-XRD peaks & & & & & & & & \\
\hline CdG16 & & & No $\mu$-XRD peaks & & & & & & & & \\
\hline
\end{tabular}

${ }^{a}$ Value set to 1 because the $a$ parameter is equal or smaller than the value for the $\mathrm{CdCO}_{3}$ end-member (otavite). W, whewellite $\left(\mathrm{CaC}_{2} \mathrm{O}_{4} \cdot \mathrm{H}_{2} \mathrm{O}\right) ; \mathrm{A}$, aragonite $\left(\mathrm{CaCO}_{3}\right) ;(\mathrm{t})$, trace amounts. -, element not detected by $\mu-\mathrm{XRF}$ and EDX.

$r=0.72 \AA), \operatorname{Mn}(r=0.83 \AA)$, and $\mathrm{Cd}(r=0.95 \AA)$ for $\mathrm{Ca}$ $(r=1.00 \AA$; Shannon, 1976), based on EDX and $\mu$-XRF analyses (Figs. $1 \mathrm{~d}$ and $2 \mathrm{~d}$ ). The other rounded grains were composed also of substituted minute vaterite crystals. Their average composition varied from grain to grain, with $a$ ranging from $7.06 \AA$ to $7.09 \AA$ and $c$ from $16.70 \AA$ to $16.81 \AA$, but likely also between crystallites within the same grain.

CdCaG8 and CdCaG9 have only faceted crystals. Their spotty $\mu$-XRD patterns (Fig. 2b) indicate that only a limited number of crystals were in Bragg condition in the $\sim 16 \times$ $7 \times 10 \mu \mathrm{m}^{3}$ diffraction volume (horizontal $\times$ vertical size of the beam $x$ estimated thickness of the grain). Thus, the crystals sizes are relatively coarse. The unit cell parameters are again smaller $(a=4.91$ and $4.92 \pm 0.01 \AA$, $c=16.79$ and $16.83 \pm 0.01 \AA$ ) than those of the pure $\mathrm{CaCO}_{3}$ polymorph, here calcite $(a=4.9896 \AA, c=17.0610 \AA)$. EDX and $\mu$ $\mathrm{XRF}$ showed that $\mathrm{Mg}$ and $\mathrm{Cd}$, and to a lesser extent $\mathrm{Mn}$ and $\mathrm{Zn}$, are the most likely Ca substituents (Figs. 1f and 2e). 

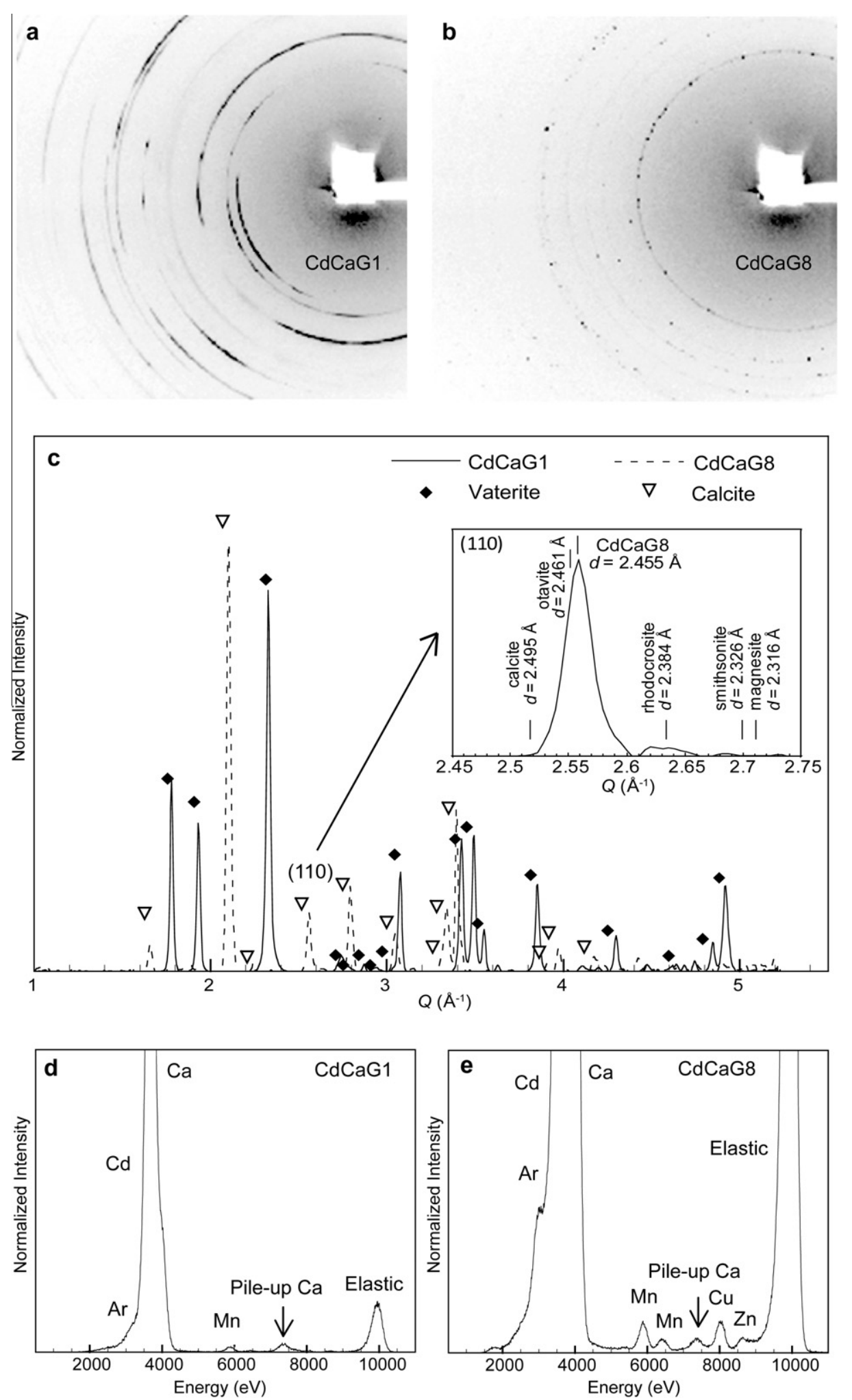

Fig. 2. Two-dimensional (a and b) and one-dimensional $\mu$-XRD patterns (c), and $\mu$-XRF spectra ( $d$ and e) for the rounded grain CdCaG1 and the faceted grain $\mathrm{CdCaG} 8$, both from the $\mathrm{Cd}+\mathrm{Ca}$ treatment. Grain $\mathrm{CdCaG1}$ contains nanometer to submicrometer-sized vaterite crystals with preferential orientation, and grain $\mathrm{CdCaG} 8$ nanometer to coarse calcite crystals. Diffraction peaks are shifted to shorter $d$ values (higher $Q$ values) as a result of $\mathrm{Cd}, \mathrm{Mn}, \mathrm{Zn}$, and/or $\mathrm{Mg}$ for $\mathrm{Ca}$ substitutions. The $\left(\begin{array}{lll}1 & 1 & 0\end{array}\right)$ reflection of the CdCaG8 grain (inset) is at $d=2.455 \AA$, compared to $2.495 \AA$ for calcite, $2.461 \AA$ for otavite $\left(\mathrm{CdCO}_{3}\right), 2.384 \AA$ for rhodocrosite $\left(\mathrm{MnCO}_{3}\right), 2.326 \AA$ for smithsonite $\left(\mathrm{ZnCO}_{3}\right)$, and $2.316 \AA$ for magnesite $\left(\mathrm{MgCO}_{3}\right)$. 

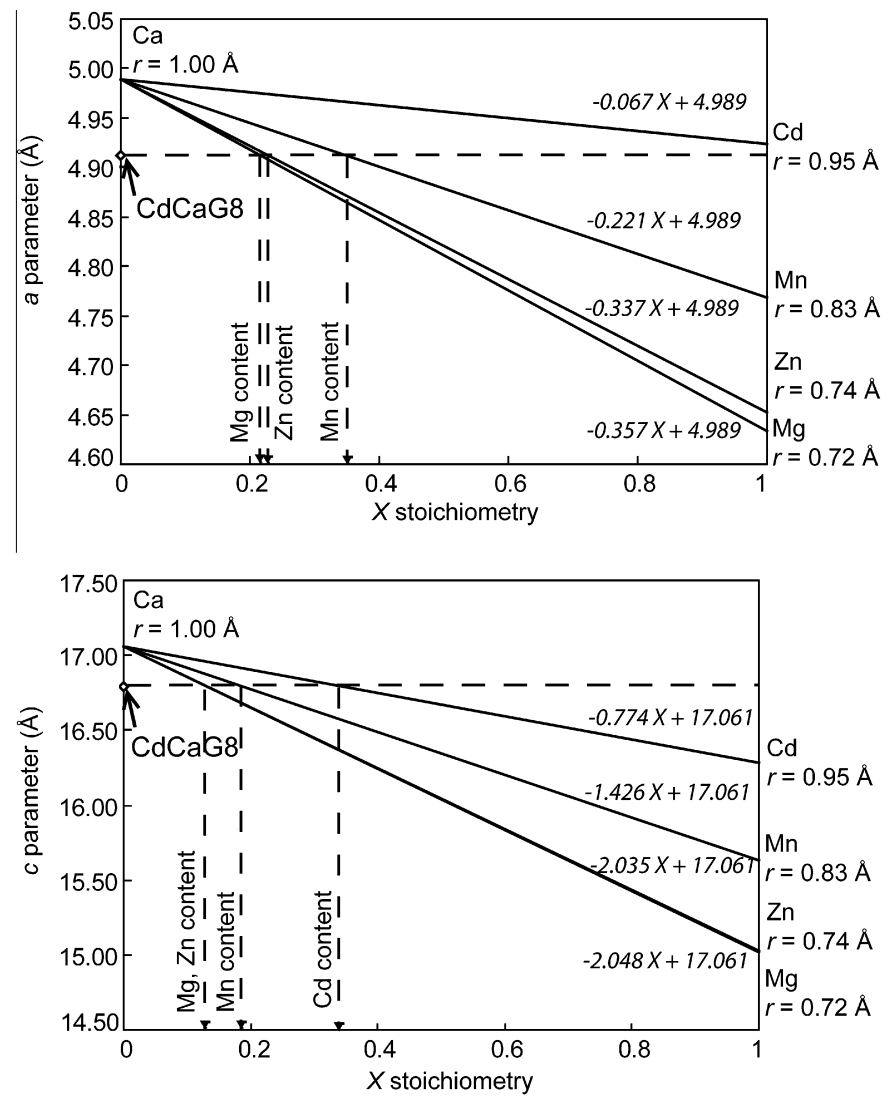

Fig. 3. Vegard diagrams for the $a$ and $c$ parameters of calcite, as first end-member, and of $\mathrm{Cd}, \mathrm{Mn}, \mathrm{Zn}$, and $\mathrm{Mg}$ carbonates, as second endmember. They were used to calculate the maximum amounts of metal substituents in $\mathrm{Me}_{x} \mathrm{Ca}_{1-x} \mathrm{CO}_{3}$ crystals.

Assuming that each diffracting calcite crystal contains only one substitutional cation, a theoretical stoichiometry can be calculated from the Vegard law using the $a$ or $c$ parameters (Fig. 3). The precision with $c$ is higher, because this metrical parameter is more sensitive to the substitution rate than is $a$. For an uncertainty on $a$ and $c$ of \pm $0.01 \AA$, the precisions in mole fractions are $\pm 1.3 \%$ of total cation for $\mathrm{Cd}, 0.7 \%$ for $\mathrm{Mn}, 0.5 \%$ for $\mathrm{Zn}$, and $0.5 \%$ for $\mathrm{Mg}$ with $c$, and $\pm 15 \% \mathrm{Cd}, 4.5 \% \mathrm{Mn}, 3.0 \% \mathrm{Zn}$, and $2.8 \% \mathrm{Mg}$ with $a$. Using $c$, the calcite crystals in CdCaG8 contain on average and at most, 13-14 at.\% Mg, 13-14 at. $\% \mathrm{Zn}, 18-20$ at. $\% \mathrm{Mn}$, and $34-36$ at. $\% \mathrm{Cd}$. The $a$ parameter gives 19 - 25 at. $\% \mathrm{Mg}, 20-27$ at. $\% \mathrm{Zn}$, and 31-40 at.\% Mn. CdCaG9 has the same average degree of substitution as $\mathrm{CdCaG} 8$ (Table 1), despite the generally heterogeneous composition of individual crystallites in trichome grains (Sarret et al., 2007). The maximum mole fraction of $\mathrm{Cd}$ could not be calculated in the two grains, because the experimental $a$ value (4.91 and $4.92 \pm 0.01 \AA$ ) is smaller or identical to that of the pure end-member otavite $(4.923 \AA)$. Therefore, the contraction of the unit cell is not due to $\mathrm{Cd}$ alone, this impurity coexists with at least one smaller cation, likely $\mathrm{Mg}$ because this was the main impurity in calcite from the $\mathrm{Ca}$ treatment.

Within precision, the level of metal substitution seems to be higher in the $a$ than in the $c$ direction. This anisotropic lattice distortion may have two origins, which both result in a lesser reduction of the $c$ parameter relative to $a$. One is the disordering of cations over the two nonequivalent $\mathrm{Ca}$ sites of calcite, as in thermally-treated dolomite $\left(\mathrm{CaMg}\left(\mathrm{CO}_{3}\right)_{2}\right.$; Reeder and Wenk, 1983; Bromiley et al., 2007). The other is the incorporation in the structure of organic molecules, as in biogenic carbonates from mollusk shells (Pokroy et al., 2006; Zolotoyabko and Pokroy, 2007).

The other grains $(\mathrm{CdCaG} 10$ and $\mathrm{CdCaG} 11)$ contain calcite and vaterite. Vaterite has about 2.5 times more $\mathrm{Cd}$ than calcite. The $\mathrm{Ca}$ oxalate monohydrate whewellite $(\mathrm{W}, \mathrm{Ca}-$ $\mathrm{C}_{2} \mathrm{O}_{4} \cdot \mathrm{H}_{2} \mathrm{O}$ ) occurred occasionally as trace mineral in some grains. One grain $(\mathrm{CdCaG12})$ did not diffract nor had detectable $\mathrm{Cd}$, although it was rich in $\mathrm{Ca}$, probably in an amorphous phase.

\subsubsection{Cd treatment}

Sixteen grains were examined by $\mu-X R D$ (Table 1). Calcite grains were most prevalent and generally more substituted than in the $\mathrm{Ca}+\mathrm{Cd}$ treatment. Their $\mu$-XRD patterns showed spots from relatively coarse calcite crystals mixed with continuous Debye rings from minute calcite particles (CdG1, CdG3, Fig. 4). CdG12 was the only grain with substituted vaterite in addition to substituted calcite (Fig. 5). When present, whewellite and aragonite were subordinate to calcite and vaterite. Four Ca-rich grains did not produce a diffraction signal, which suggests a non-crystalline Ca-containing organic or inorganic phase. Cadmium was not detected, except for CdG12. 

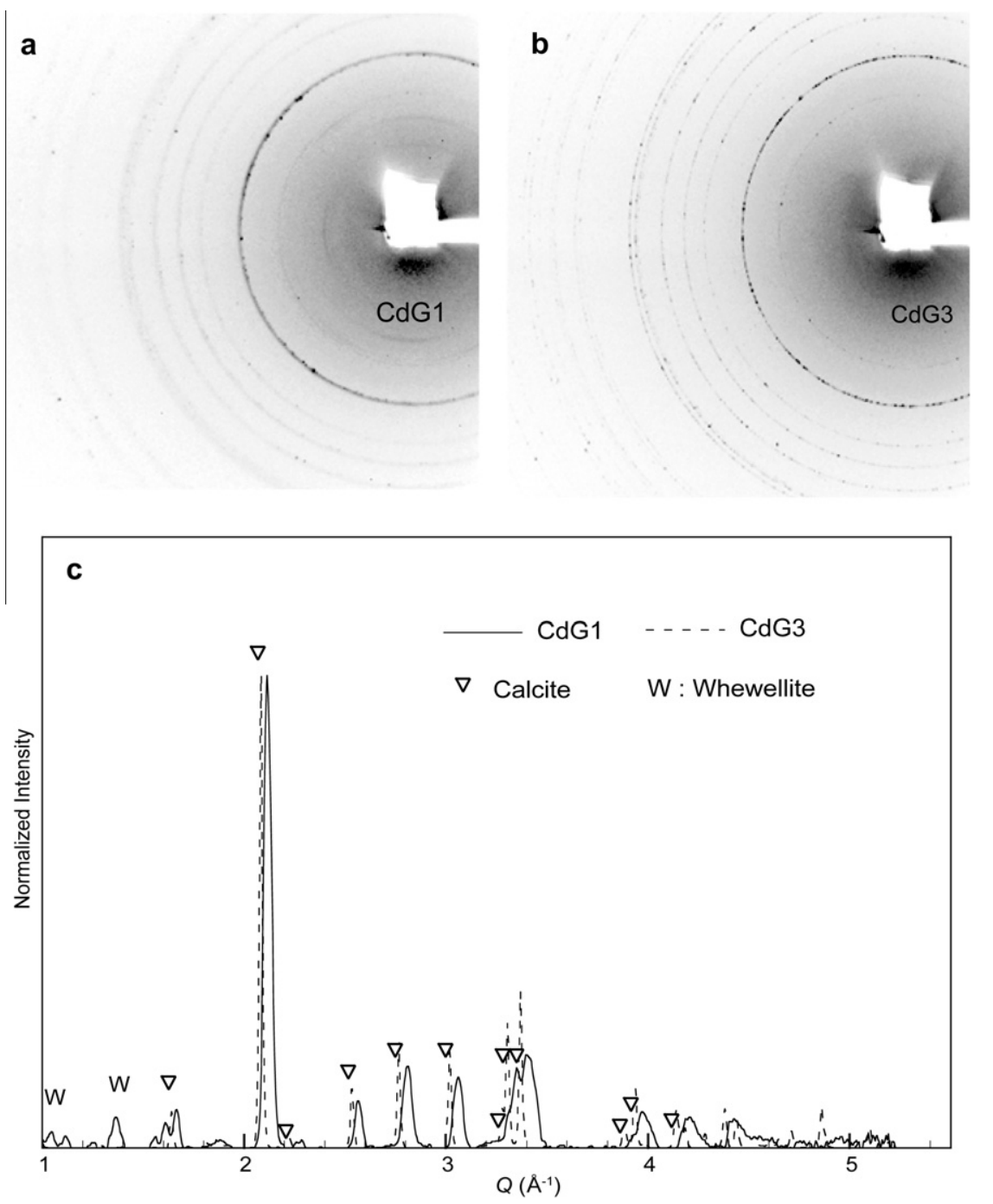

Fig. 4. $\mu$-XRD patterns for grains $\mathrm{CdG} 1$ (a) and $\mathrm{CdG} 3$ (b) in the $\mathrm{Cd}$ treatment. Grain CdG1 contains major nanometer and minor coarse crystals of calcite, and whewellite $\left(\mathrm{W}: \mathrm{CaC}_{2} \mathrm{O}_{4} \cdot \mathrm{H}_{2} \mathrm{O}\right.$ ). Micrometric calcite crystallites are more abundant in grain CdG3. Diffractions peaks are shifted to smaller $d$ values relative to pure calcite due to the presence of $\mathrm{Cd}, \mathrm{Mn}, \mathrm{Zn}$, or Mg impurities (Table 1).

\subsubsection{Ca treatment}

The grains consisted mainly of $(\mathrm{Mg}, \mathrm{Mn})$-substituted calcite, along with subordinate amounts of whewellite (Ca$\left.\mathrm{C}_{2} \mathrm{O}_{4} \cdot \mathrm{H}_{2} \mathrm{O}\right)$, weddellite $\left(\mathrm{CaC}_{2} \mathrm{O}_{4} \cdot 2 \mathrm{H}_{2} \mathrm{O}\right)$, and vaterite, as previously reported for this type of treatment (Sarret et al., 2006, 2007).

\subsection{Cd speciation}

\subsubsection{Reference compounds}

The $\mathrm{Cd} \mathrm{L}_{\mathrm{III}}$-edge $\mu$-XANES spectra of the references have a peak at $\sim 3540 \mathrm{eV}$ when $\mathrm{Cd}$ is bonded to $\mathrm{O}$ ligands, not when it is bonded to $\mathrm{S}$ ligands, as observed for CdS and Cd-cysteine (Fig. 6; Pickering et al., 1999; Isaure et al., 2006). Among the references with $\mathrm{O}$ ligands, those in which $\mathrm{Cd}$ is bound to $\mathrm{COOH} / \mathrm{OH}$ groups $(\mathrm{Cd}$ cell wall, Cd-malate, Cd-citrate, Cd-oxalate and Cd-pectin) and to phosphate (Cd-phosphate) are featureless compared to the other references and to aqueous $\mathrm{Cd}$
$\left(\mathrm{Cd}_{\mathrm{aq}}\right)$. The six $\mathrm{Cd}$-containing calcium carbonate spectra are well structured, and distinct from the other reference spectra. The spectra of otavite and Cd-containing calcites show a pronounced peak at $3551 \mathrm{eV}$, but the otavite spectrum has in addition a shoulder at $3547 \mathrm{eV}$ (arrow in Fig. 6). The similarity of the spectra for the four Cd-containing calcites (Cd10, Cd100, (Cd100, Mg100), and Cdsorbed) suggests a common structural geometry of their bonding environment. This observation is consistent with the formation of a $(\mathrm{Ca}, \mathrm{Cd}) \mathrm{CO}_{3}$ solid solution at the calcite surface exposed to $0.1 \mu \mathrm{M} \mathrm{Cd}$ for $24 \mathrm{~h}$ (Chada et al., 2005). In the following, the four samples are named by the same generic expression "Cd-containing calcite". A lower amplitude of the peak at $3551 \mathrm{eV}$ is distinctive of Cd100-vaterite.

\subsubsection{Nature of $C d$ species in tobacco grains}

All tobacco grain spectra show a peak at $3540 \mathrm{eV}$, indicating that $\mathrm{Cd}$ is coordinated to oxygen atoms (Fig. 6). Six 

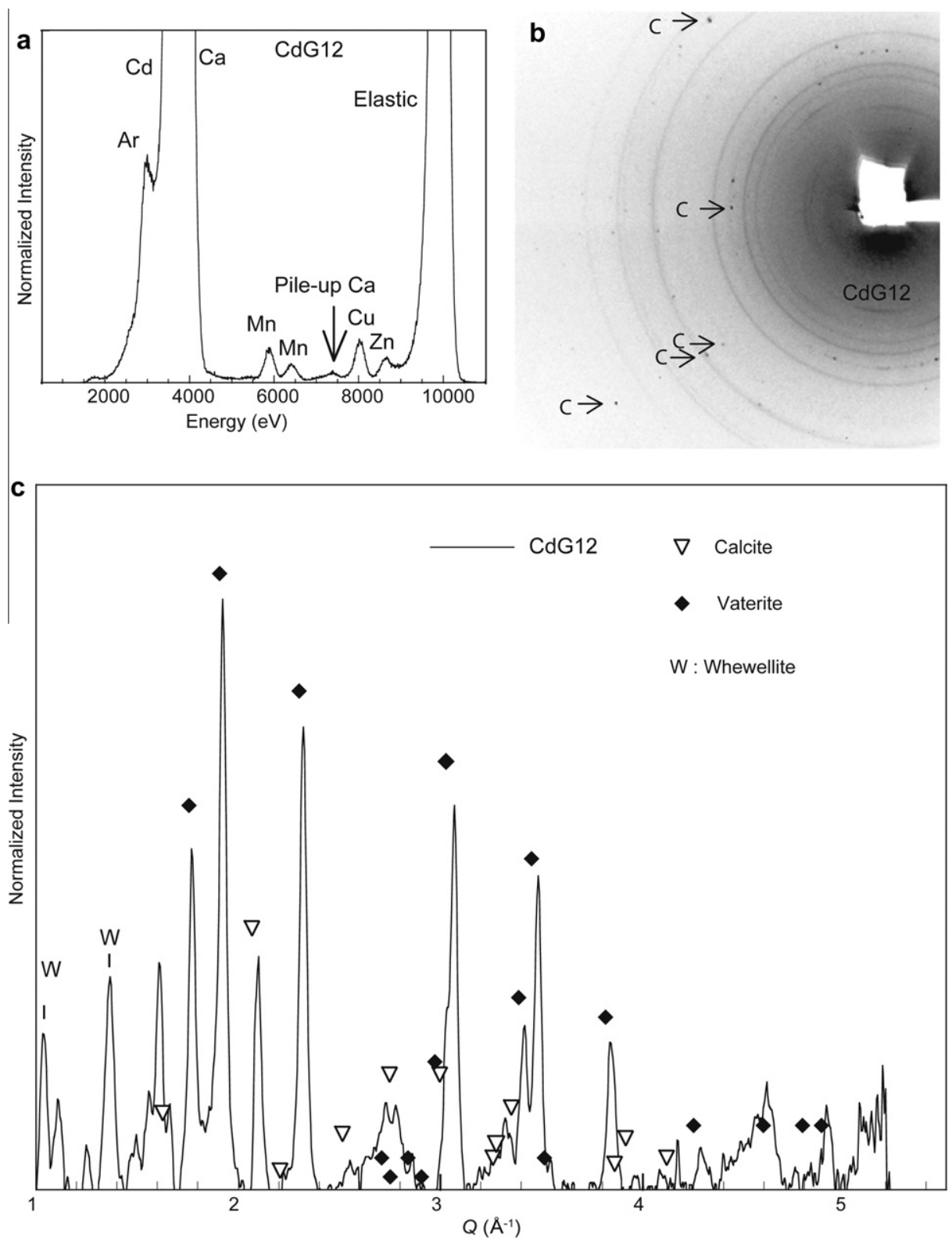

Fig. 5. $\mu$-XRF spectra (a) and $\mu$-XRD patterns ( $\mathrm{b}$ and $\mathrm{c}$ ) for grain $\mathrm{CdG} 12$ in the $\mathrm{Cd}$ treatment. This grain contains major nanometer vaterite, and minor coarse crystals of calcite and whewellite $\left(\mathrm{W}: \mathrm{CaC}_{2} \mathrm{O}_{4} \cdot \mathrm{H}_{2} \mathrm{O}\right)$. The two carbonates are substituted.

out of the nine $\mathrm{Cd}+\mathrm{Ca}$ grains spectra resemble $\mathrm{Cd} 100-$ vaterite, whereas the others $(\mathrm{CdCaG} 7, \mathrm{CdCaG} 8$, and $\mathrm{CdCaG9)}$ have more similarities with Cd-containing calcite. Only two spectra could be recorded for the Cd treatment (CdG1 and CdG12), because of the low concentration of $\mathrm{Cd}$. Although extremely noisy, the CdG1 spectrum resembles Cd-containing calcite, whereas CdG12 has more similarities with Cd100-vaterite.

PCA was performed on the whole set of tobacco grain spectra, except CdG1. Based on the IND local minimum criterion, the dataset contains three independent components (i.e., Cd species; Fig. 7). However, examination of the first five principal components suggests that only the first two may be meaningful; the third is weak and does not appear sufficiently modulated to justify its inclusion in the PCA. Because the IND determination method is not fully accepted (Manceau et al., 2002; Sarret et al., 2004; Panfili et al., 2005; Kirpichtchikova et al., 2006; Manceau and Matynia, 2010), and visual inspection is too subjective, the target transformations were performed with two and three components.

Good spectral match of the reference spectra to the principal components were obtained with Cd-containing calcite $\left(N S S=4.2 \times 10^{-4}, S=0.7\right.$, and $N S S=3.8 \times 10^{-4}, S=$ 1.8 , with two and three principal components, respectively) and Cd100-vaterite ( $N S S=7.6 \times 10^{-4}, S=3.0$ and $N S S=2.8 \times 10^{-4}, S=2.3$; Fig. 8). The spectra for Cd-cell wall $\left(N S S=17.2 \times 10^{-4}, S=3.0\right.$ and $N S S=14.3 \times 10^{-4}$, $S=4.7)$, Cd-pectin $\left(N S S=32.1 \times 10^{-4}, S=3.6\right.$, and $N S S=$ $24.6 \times 10^{-4}, S=4.7$, not shown), Cd-cellulose (NSS $=$ 


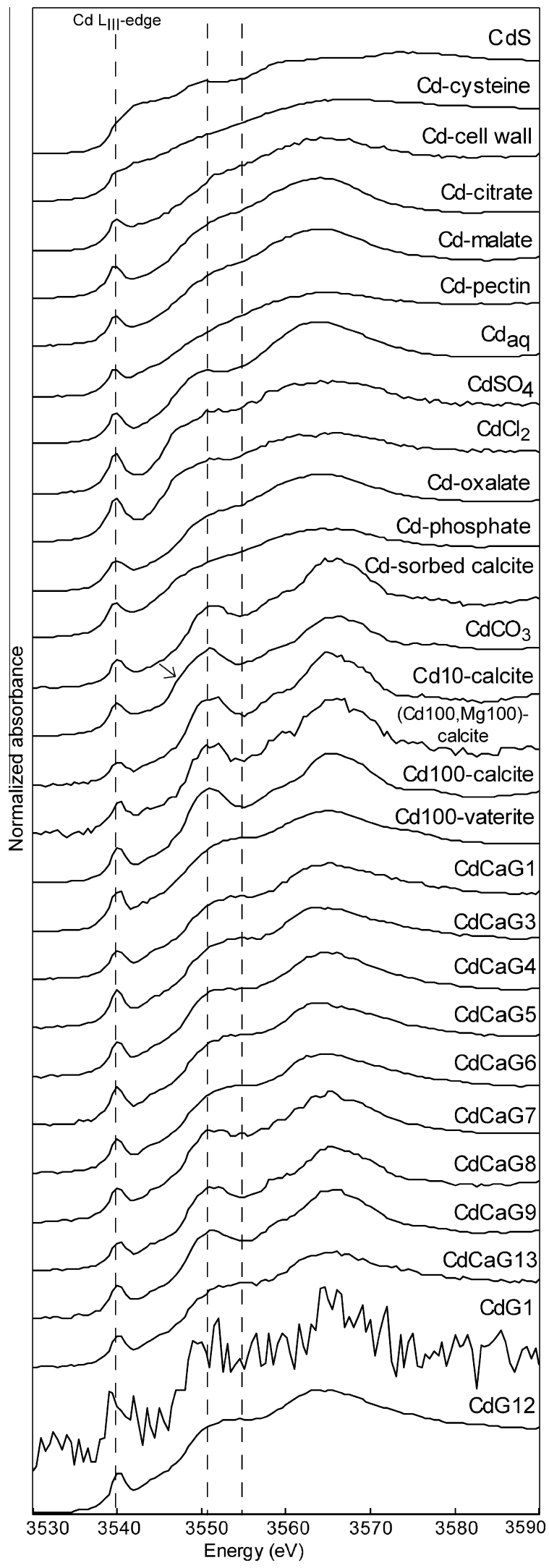

Fig. 6. $\mathrm{Cd} \mathrm{L}_{\mathrm{III}}$-edge $\mu$-XANES spectra for a selection of reference compounds and grains from the Cd treatment (CdG1 and CdG12), and $\mathrm{Cd}+\mathrm{Ca}$ treatment (all others).
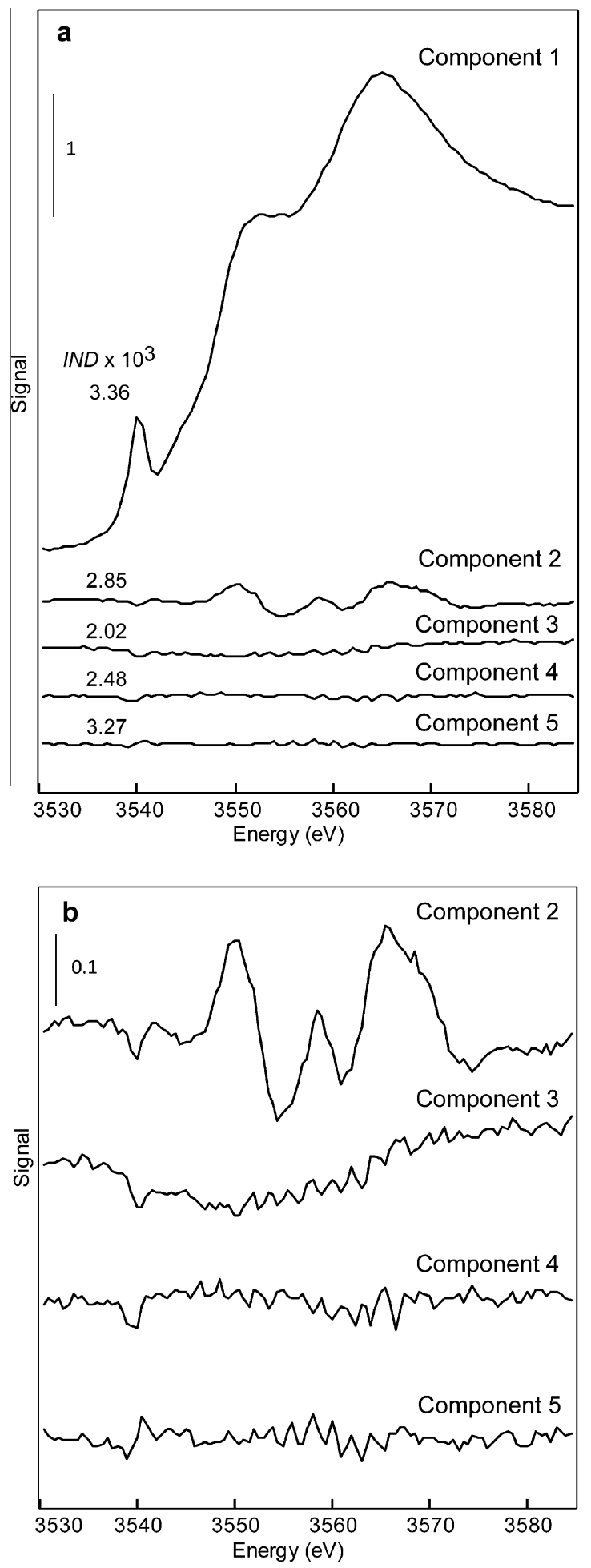

Fig. 7. First five components calculated by PCA (a) and enlargement of components 2-5 (b).

$19.2 \times 10^{-4}, S=3.9$, and $N S S=18.3 \times 10^{-4}, S=6.8$, not shown), and Cd-malate $\left(N S S=21.2 \times 10^{-4}, S=5.0\right.$, and $\left.N S S=19.9 \times 10^{-4}, S=8.1\right)$ considered as proxies for $\mathrm{Cd}$ bound to $\mathrm{COOH} / \mathrm{OH}$ groups of organic compounds, and 

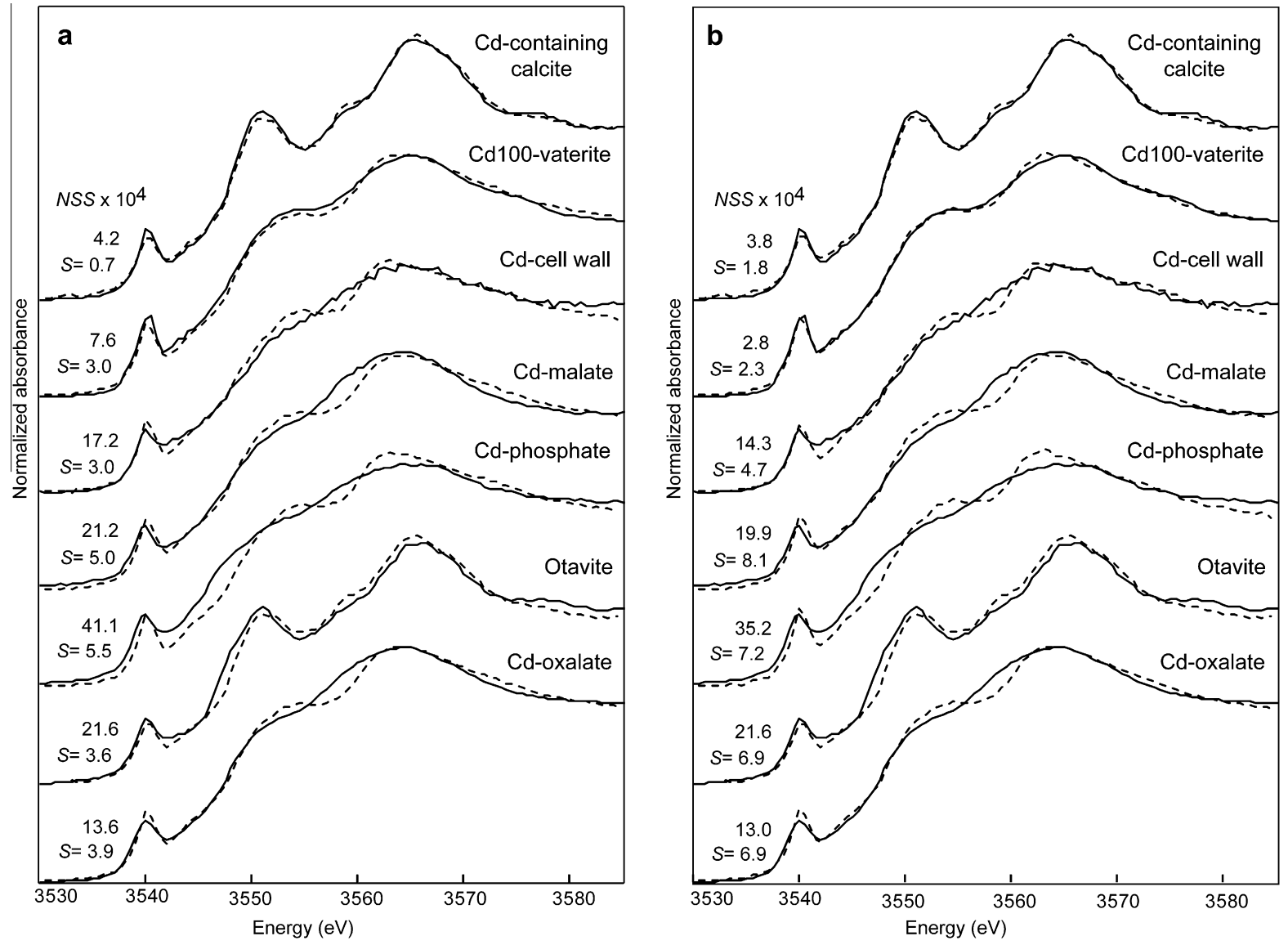

Fig. 8. $\mathrm{Cd} \mathrm{L}_{\mathrm{III}}$-edge $\mu$-XANES spectra (solid lines) and target transformations (dashed lines) of a selection of Cd reference compounds using the first two (a) and three (b) principal components from Fig. 5. The quality of the transformation was evaluated with the SPOIL (S) and NSS parameters. Cd-containing calcite and Cd100-vaterite are the two dominant $\mathrm{Cd}$ species.

Cd-phosphate $\left(N S S=41.1 \times 10^{-4}, S=5.5\right.$, and $N S S=$ $\left.35.2 \times 10^{-4}, S=7.2\right)$, otavite $\left(N S S=21.6 \times 10^{-4}, S=3.6\right.$, and $N S S=21.6 \times 10^{-4}, S=6.9$ ), and Cd-oxalate (NSS= $13.6 \times 10^{-4}, S=3.9$, and $\left.N S S=13.0 \times 10^{-4}, S=6.9\right)$ were not well reconstructed, regardless of the number of principal components used in the target transformation. These results suggest that $\mathrm{Cd}$ is mainly precipitated as carbonates in all grains.

\subsubsection{Proportions of Cd species in tobacco grains}

The proportions of the two $\mathrm{Cd}$ carbonate species (i.e., calcite and vaterite) in the nine grains from the $\mathrm{Cd}+\mathrm{Ca}$ treatment and the two grains from the $\mathrm{Cd}$ treatment (CdG1, CdG12) were determined next by LSF of the experimental spectra to linear combinations of the Cd-containing calcite and Cd100-vaterite reference spectra (Table 2, Fig. 9). Best one-component fits were obtained with Cdcontaining calcite for $\mathrm{CdCaG} 7, \mathrm{CdCaG} 8, \mathrm{CdCaG} 9$, and $\mathrm{CdG1}$, and with $\mathrm{Cd} 100$-vaterite for the other grains. Adding Cd100-vaterite to the calcitic grains much improved the reconstruction of $\mathrm{CdCaG} 7$ (NSS decreased from $20 \times 10^{-4}$ to $3.7 \times 10^{-4}$ ), but not those of the three other grains. However, the NSS values of CdCaG8 and CdCaG9 could be reduced by $40 \%$ upon adding $16-18 \%$ of a Cd-or- ganic species. This species is minor (close to the detection limit), and there was no other circumstantial evidence for its presence in other grains, which may explain why it was not identified by PCA. Organically bound $\mathrm{Zn}$ and $\mathrm{Ca}$ also were minor species in the tobacco grains studied previously (Sarret et al., 2007). The two-component fits of the grain spectra, in which Cd100-vaterite was dominant, identified Cd-containing calcite in two grains: CdCaG4 and CdG12.

Thus, among the eleven grains examined by XANES, $\mathrm{Cd}$ is present only or predominantly in calcite in three grains ( $\mathrm{CdCaG} 8, \mathrm{CdCaG} 9$ and $\mathrm{CdG} 1)$, evenly distributed between calcite and vaterite in one grain $(\mathrm{CdCaG} 7)$, and only or predominantly in vaterite in the others. Four grains (CdCaG1, CdCaG7, CdCaG12, CdG12) were studied previously by Ca-XANES (Sarret et al., 2007). Calcite and vaterite had been also identified by this technique, except $\mathrm{CdCaG} 12$ in which the $\mathrm{Ca}$ carbonate species was non-crystalline (Table 1).

\subsection{Relationship between Cd speciation and morphology/ mineralogy of the tobacco grains}

The nature of the Cd host phases, as determined by $\mu$ XANES, is consistent with the mineralogy of the crystalline 
Table 2

Proportion of Cd species (in $\%$ mole fraction) determined by LSF of the $\mathrm{Cd} \mathrm{L}_{\mathrm{III}}$-edge $\mu$-XANES spectra.

\begin{tabular}{|c|c|c|c|c|c|c|}
\hline & Cd-containing calcite $(\%)$ & Cd100-vaterite $(\%)$ & Cd-organic $(\%)$ & Sum & $N S S_{\text {best }}{ }^{\mathrm{a}}\left(\times 10^{4}\right)$ & $I^{\mathrm{b}}(\%)$ \\
\hline \multicolumn{7}{|c|}{$\begin{array}{l}\text { Grains from the } \mathrm{Cd}+\mathrm{Ca} \text { treatment } \\
\mathrm{CdCaG1}\end{array}$} \\
\hline $\begin{array}{l}\text { One component } \\
\mathrm{CdCaG3}\end{array}$ & & 85 & & 85 & 5.4 & \\
\hline $\begin{array}{l}\text { One component } \\
\text { CdCaG4 }\end{array}$ & & 93 & & 93 & 3.2 & \\
\hline One component & & 96 & & 96 & 8.6 & \\
\hline $\begin{array}{l}\text { Two components } \\
\text { CdCaG6 }\end{array}$ & 30 & 67 & & 97 & 3.0 & 65 \\
\hline $\begin{array}{l}\text { One component } \\
\mathrm{CdCaG5}\end{array}$ & & 91 & & 91 & 3.7 & \\
\hline $\begin{array}{l}\text { One component } \\
\text { CdCaG7 }\end{array}$ & & 95 & & 95 & 4.2 & \\
\hline One component & 104 & & & 104 & 20 & \\
\hline $\begin{array}{l}\text { Two components } \\
\text { CdCaG8 } 8\end{array}$ & 52 & 51 & & 103 & 3.7 & 81 \\
\hline One component & 90 & & & 90 & 6.3 & \\
\hline $\begin{array}{l}\text { Two components } \\
\text { CdCaG9 }\end{array}$ & 76 & & 16 & 92 & 3.7 & 41 \\
\hline One component & 98 & & & 98 & 6.6 & \\
\hline $\begin{array}{l}\text { Two components } \\
\text { CdCaG13 }\end{array}$ & 83 & & 18 & 101 & 3.5 & 47 \\
\hline One component & & 87 & & 87 & 4.1 & \\
\hline $\begin{array}{l}\text { Grains from the } \mathrm{Cc} \\
\mathrm{CdG} 1\end{array}$ & atment & & & & & \\
\hline $\begin{array}{l}\text { One component } \\
\text { CdG12 }\end{array}$ & 107 & & & 107 & 311 & \\
\hline One component & & 105 & & 105 & 3.6 & \\
\hline Two components & 15 & 91 & & 106 & 2.2 & 39 \\
\hline
\end{tabular}

${ }^{\mathrm{a}}$ Residual (normalized sum squares) between fit and experimental data: $N S S_{\text {best }}=\left[\Sigma\left(\right.\right.$ Normalized Absorption ${ }_{\text {th }}-$ Normalized Absorption $\left.\left._{\text {exp }}\right)^{2} / \Sigma\left(\text { Normalized Absorption }{ }_{\text {exp }}\right)^{2}\right] \times 100$, in the 3530-3585 eV interval.

${ }^{\mathrm{b}}$ Improvement of the fit: $I=\left[\left(N S S_{n} \text { components }-N S S_{n+1} \text { component } / N S S_{n \text { component }}\right]^{*} 100\right.$. The fit components are precise to $20 \%$ of total Cd. The precision on Cd-organic is slightly better, approximately $10-15 \%$. The sum of the Cd component(s) deviates from $100 \%$ for two reasons, one is the precision of each component, the other is the accuracy of the method itself. See Van Damme et al. (2010) for details.

phases, as determined by $\mu$-XRD, except for CdCaG4 (Table 3). Vaterite was identified by the two techniques in this grain, but the second species, Cd-substituted calcite, only by spectroscopy. A likely reason is the difference in sample volume probed by the two techniques. For $\mu$-XRD measurements, the beam size was $16 \times 7 \mu \mathrm{m}^{2}$ and the penetration depth from several tens to a few hundreds of $\mu \mathrm{m}$ at $17 \mathrm{keV}$, whereas they were $0.70 \times 0.35 \mu \mathrm{m}^{2}$ and a few $\mu \mathrm{m}$ at the $\mathrm{Cd} \mathrm{L}_{\mathrm{III}}$-edge for $\mu$-XANES. Thus, the detection by $\mu$-XANES of calcite in this vaterite-rich grain suggests that it contains euhedral calcite crystals at it surface, as observed for CdG12 (Fig. 1j).

\section{DISCUSSION}

\subsection{Calcium biomineralization and Cd elimination in tobacco grains}

Calcium carbonate is a common biogenic mineral in the Animalia kingdom (Weiner and Dove, 2003). In Plantae, it is biosynthesized in few families, such as Moraceae, Urticaceae, and Acanthaceae, generally occurring as intercellular concretions (cystolith) (Arnott and Pautard, 1970; Setogu- chi et al., 1989; Nitta et al., 2006). In contrast to calcium carbonate in animals, calcium oxalate is probably the most commonly formed mineral in higher plants (Franceschi and Homer, 1980). The monohydrated form (whewellite) is more frequent than the anhydrous (weddelite). These crystals can form in most tissues and organs, such as roots, bark, stems, leaves, flowers, fruits, and seeds (Arnott and Pautard, 1970). In tobacco, they occur in the vacuoles of specialized cells called idioblasts (Bouropoulos et al., 2001). Oxalate biocrystals play a central role in a variety of important functions, including tissue calcium regulation, osmotic balance, protection from herbivory, metal detoxification, and improvement of the mechanical properties of the tissues (Nakata, 2003; Franceschi and Nakata, 2005). Intra-cellular detoxification of $\mathrm{Cd}$ by calcium oxalate was reported in water hyacinth (Mazen and El Maghraby, 1997).

In tobacco, calcium has a protective effect against $\mathrm{Cd}$ toxicity: the amounts of grains per mass of dry matter is low under $\mathrm{Cd}$ exposure alone, moderate under $\mathrm{Ca}$ exposure, and high under $\mathrm{Cd}+\mathrm{Ca}$ exposure (Choi et al., 2001; Choi and Harada, 2005). Apparently, calcium does not compete with $\mathrm{Cd}$ for uptake by roots, but instead pro- 


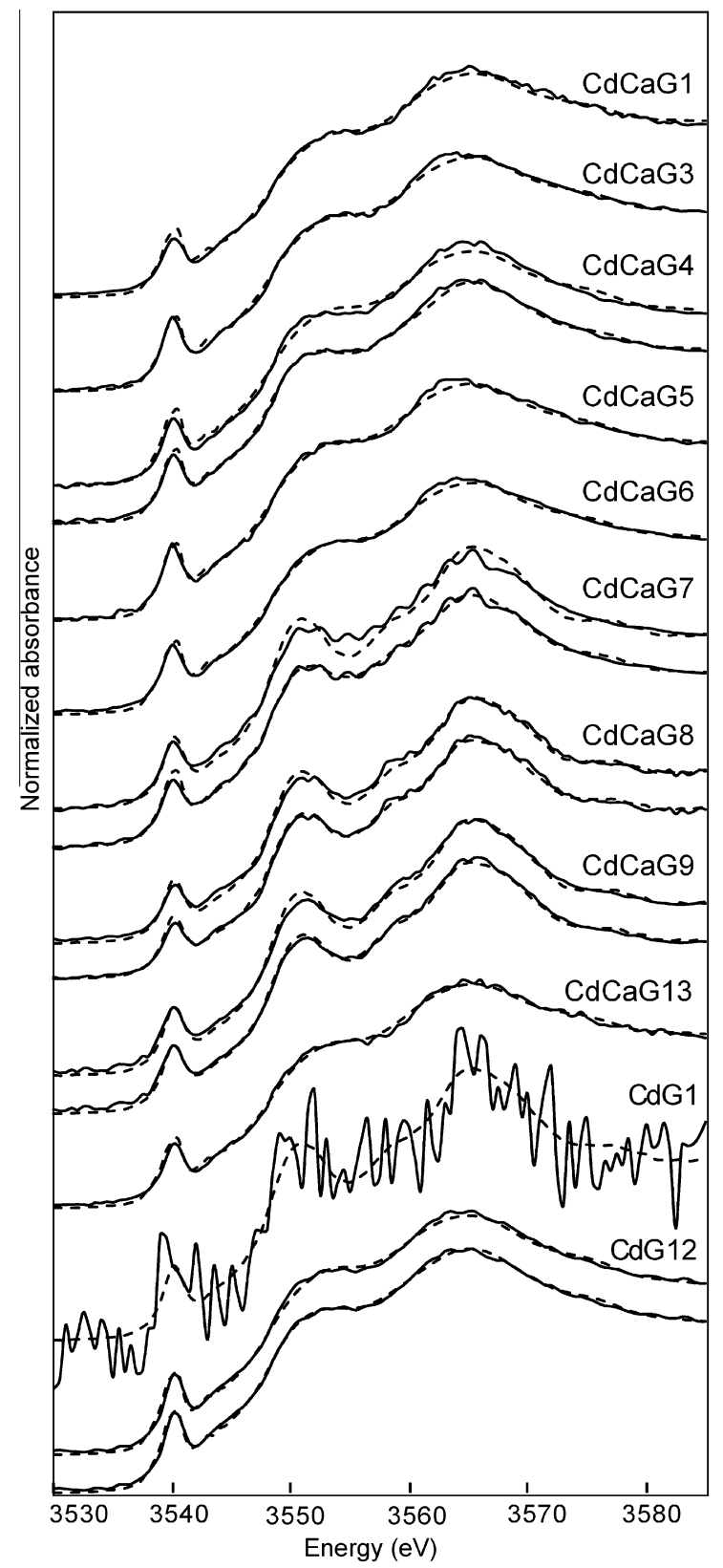

Fig. 9. $\mathrm{Cd} \mathrm{L}_{\mathrm{III}}$-edge $\mu$-XANES spectra for tobacco grains (solid lines) and best linear combination fits (dashed lines) with one or two components ( $\mathrm{CdCaG} 4, \mathrm{CdCaG} 7, \mathrm{CdCaG} 8, \mathrm{CdCaG} 9$, and CdG12).

vides powerful synergy for Cd detoxification by trichomes. Calcium does more than increasing the density of trichomes at the leaf surface, it modifies also the $\mathrm{Ca} / \mathrm{Cd}$ ratio, morphology, mineralogy, and $\mathrm{Cd}$ speciation of the grains. Under $\mathrm{Cd}+\mathrm{Ca}$ treatment, a higher proportion of grains have a ball shape with a surface like an orange peel made of Cd-containing vaterite, whereas under low Ca supplement the grains look like calcite crystals with well-developed crystallographic faces and little $\mathrm{Cd}$. Cadmium is more concentrated in biogenic vaterite than in biogenic calcite, whereas the reverse was observed in abiotic grains.
This difference may result from the presence of organics in biotic grains.

\subsection{Biologically induced or biologically controlled mechanism?}

The mechanism of grain formation is as yet unknown. Considerations of the size of the grains $(20-150 \mu \mathrm{m})$ and diameter of the head of trichomes $(<20 \mu \mathrm{m}$; Choi et al., 2001) lead to the conclusion that precipitation results from the contact with atmosphere of a Ca-rich exudate. The heterogeneity and variability in morphology, composition and structure of the grains also are suggestive of a "biologically induced" process (Sarret et al., 2006). The general relationships between the shape (spherical vs. faceted) and mineralogy (vaterite vs. calcite) of the grains, on one hand, and the amount of $\mathrm{Ca}$ in the nutritive solution $(\mathrm{Cd}+\mathrm{Ca}$ vs. $\mathrm{Cd}$ treatment), on the other, reinforces the idea that this biomineralization does not depend on the plant cellular activity itself but is determined by the chemistry of exudates.

\subsection{Occurrence and stabilization of vaterite}

Vaterite is thermodynamically the most unstable polymorph of the three crystal structures of $\mathrm{CaCO}_{3}$, and rapidly transforms into aragonite or calcite (Ogino et al., 1987; Kralj et al., 1997; Vecht and Ireland, 2000; Nehrke and Van Cappellen, 2006; Rieger et al., 2007). It can be stabilized by organic molecules (Colfen and Antonietti, 1998; Naka and Chujo, 2001; Falini et al., 2005; Rodriguez-Navarro et al., 2007; Qiao et al., 2008), such as proteins (Kanakis and Dalas, 2000; Rautaray et al., 2005), exopolysaccharides and carboxylic molecules (Dalas et al., 1999; Manoli and Dalas, 2001; Braissant et al., 2003; Malkaj and Dalas, 2004; Naka et al., 2006), and amino acids (Manoli et al., 2002; Lakshminarayanan et al., 2005; Xie et al., 2005). Consequently, abiotic vaterite is rare in nature (Rowlands and Webster, 1971; Lucas and Andrews, 1996), and more common in biota (Lowenstam and Weiner, 1989; Mann, 2001). Reported occurrences include the spicule of Ascidiacea marine organisms (Lowenstam and Abbott, 1975), fish otoliths (Cyprinids) (Falini et al., 2005; Lenaz et al., 2006), freshwater pearls (Qiao and Feng, 2007; Qiao et al., 2008), microbial mats from lake sediments (Giralt et al., 2001), avian and turtle eggshells (Dennis et al., 1996; Lakshminarayanan et al., 2005), larval shell of a freshwater snail (Hasse et al., 2000), and human gallstones where it is associated with cholesterol (Palchik and Moroz, 2005).

At the trichome surface, the biomineralization of vaterite may occur by a mechanism analogous to the proteinmediated reaction of aqueous $\mathrm{Ca}^{2+}$ with $\mathrm{CO}_{2}$, and the subsequent precipitation of stable vaterite crystals of spherical morphology described at the surface of actinomycetes, fungi, and chickpea roots (Rautaray et al., 2004; 2005). Tobacco trichomes excrete organic substances, including alkaloids such as nicotine, terpenoids (Callow et al., 2000), and defensive proteins (Wagner et al., 2004; Shepherd et al., 2005; Schilmiller et al., 2008). Further investigations are needed to determine the exact nature of organic compounds in 
Table 3

Summary of the information obtained for each tobacco grain.

\begin{tabular}{|c|c|c|c|c|}
\hline & Cd speciation $(\mu-\mathrm{XANES})$ & Ca speciation $(\mu \text {-XANES })^{a}$ & Mineralogy $(\mu-X R D)$ & $\begin{array}{l}\text { Morphology } \\
\text { (SEM) }\end{array}$ \\
\hline \multicolumn{5}{|c|}{ Grains from the $\mathrm{Cd}+\mathrm{Ca}$ treatment } \\
\hline CdCaG1 & $85 \% \mathrm{Cd}$-vaterite & $\begin{array}{l}80 \% \text { vaterite }+20 \% \text { organic } \mathrm{Ca} \text { and/ } \\
\text { or ACC }\end{array}$ & Substituted vaterite & Rounded \\
\hline $\mathrm{CdCaG} 2$ & N.m. & N.m. & Substituted vaterite & Rounded \\
\hline $\mathrm{CdCaG} 3$ & $93 \% \mathrm{Cd}$-vaterite & N.m. & Substituted vaterite & N.o. \\
\hline $\mathrm{CdCaG} 4$ & $\begin{array}{l}67 \% \mathrm{Cd} \text {-vaterite }+30 \% \mathrm{Cd}- \\
\text { containing calcite }\end{array}$ & N.m. & Substituted vaterite $+\mathrm{W}(\mathrm{t})$ & N.o. \\
\hline CdCaG5 & $95 \%$ Cd-vaterite & N.m. & Substituted vaterite $+\mathrm{W}(\mathrm{t})$ & N.o. \\
\hline CdCaG6 & $91 \% \mathrm{Cd}$-vaterite & N.m. & $\begin{array}{l}\text { Substituted vaterite }+ \\
\text { substituted calcite }(\mathrm{t})+\mathrm{W}(\mathrm{t})\end{array}$ & N.o. \\
\hline $\mathrm{CdCaG} 7$ & $\begin{array}{l}52 \% \text { Cd-containing calcite }+ \\
51 \% \text { Cd-vaterite }\end{array}$ & $\begin{array}{l}90 \% \text { calcite }+10 \% \text { organic } \mathrm{Ca} \text { and/or } \\
\text { ACC }\end{array}$ & $\begin{array}{l}\text { Substituted vaterite }+ \\
\text { substituted calcite }(\mathrm{t})\end{array}$ & N.o. \\
\hline CdCaG8 & $\begin{array}{l}76 \% \mathrm{Cd} \text {-containing calcite }+ \\
16 \% \mathrm{Cd} \text {-organic }\end{array}$ & N.m. & Substituted calcite & Faceted \\
\hline CdCaG9 & $\begin{array}{l}83 \% \text { Cd-containing calcite }+ \\
18 \% \text { Cd-organic }\end{array}$ & N.m. & Substituted calcite & Faceted \\
\hline $\mathrm{CdCaG} 10$ & N.m. & N.m. & $\begin{array}{l}\text { Substituted calcite }+ \text { substituted } \\
\text { vaterite }\end{array}$ & N.o. \\
\hline CdCaG11 & N.m. & N.m. & $\begin{array}{l}\text { Substituted calcite }+ \text { substituted } \\
\text { vaterite }\end{array}$ & N.o. \\
\hline $\mathrm{CdCaG} 12$ & No Cd signal & $70 \% \mathrm{ACC}+30 \%$ undetermined & No $\mu$-XRD peak & N.o. \\
\hline CdCaG13 & $87 \%$ Cd-vaterite & N.m. & N.m. & $\begin{array}{l}\text { Rounded and } \\
\text { faceted }\end{array}$ \\
\hline \multicolumn{5}{|c|}{ Grains from the Cd treatment } \\
\hline CdG1 & $107 \%$ Cd-containing calcite & N.m. & Substituted calcite & Oblong \\
\hline $\mathrm{CdG} 2$ & No Cd signal & N.m. & Substituted calcite $+\mathrm{W}(\mathrm{t})$ & Oblong \\
\hline CdG3 & No Cd signal & N.m. & Substituted calcite & Oblong \\
\hline $\mathrm{CdG} 4$ & No Cd signal & N.m. & Substituted calcite $+\mathrm{A}$ & N.o. \\
\hline CdG5 & No Cd signal & N.m. & Substituted calcite & N.o. \\
\hline CdG6 & No Cd signal & N.m. & Substituted calcite & N.o. \\
\hline CdG7 & No Cd signal & N.m. & Substituted calcite $+\mathrm{W}+\mathrm{A}(\mathrm{t})$ & N.o. \\
\hline CdG8 & No Cd signal & N.m. & Substituted calcite $+\mathrm{W}(\mathrm{t})$ & N.o. \\
\hline CdG9 & No Cd signal & N.m. & Substituted calcite & N.o. \\
\hline CdG10 & N.m. & N.m. & Substituted calcite & N.o. \\
\hline CdG11 & N.m. & N.m. & Substituted calcite $+\mathrm{W}(\mathrm{t})$ & N.o. \\
\hline CdG12 & $\begin{array}{l}91 \% \mathrm{Cd} \text {-vaterite }+15 \% \mathrm{Cd}- \\
\text { containing calcite }\end{array}$ & $\begin{array}{l}30 \% \text { calcite }+40 \% \text { vaterite }+30 \% \\
\text { organic } \mathrm{Ca} \text { and } / \text { or ACC }\end{array}$ & $\begin{array}{l}\text { Substituted calcite }+ \text { substituted } \\
\text { vaterite }+\mathrm{W}\end{array}$ & $\begin{array}{l}\text { Rounded }+ \\
\text { Angular edges }\end{array}$ \\
\hline CdG13 & No Cd signal & N.m. & No $\mu$-XRD peak & N.o. \\
\hline CdG14 & No Cd signal & N.m. & No $\mu$-XRD peak & N.o. \\
\hline CdG15 & N.m. & N.m. & No $\mu$-XRD peak & N.o. \\
\hline CdG16 & N.m. & N.m. & No $\mu$-XRD peak & N.o. \\
\hline
\end{tabular}

${ }^{a}$ Sarret et al. (2007). ACC, amorphous calcium carbonate (e.g., cystolith). W, whewellite $\left(\mathrm{CaC}_{2} \mathrm{O}_{4} \cdot \mathrm{H}_{2} \mathrm{O}\right) . \mathrm{A}$, aragonite $(\mathrm{CaCO})$. (t), trace amounts. N.m., not measured; N.o., not observed. CdCaG1, CdCaG7, CdCaG12 and CdG12 were named CdCa3, CdCa2, CdCa6, and Cd10, respectively, in Sarret et al. (2007).

contact with vaterite crystals, and their possible role in the texturing of the vaterite microcrystals (Fig. 2a). Microtwinning of biogenic vaterite along the $\left(\begin{array}{lll}0 & 0 & 1\end{array}\right)$ direction was observed by high-resolution transmission electron microscopy (HRTEM) and selected area electron diffraction (SAED) in freshwater lackluster pearls (Qiao and Feng, 2007). The $\mu$-XRD pattern from grain $\mathrm{CdCaG} 1$ suggests that the vaterite crystals are a mosaic of crystalline blocks tilted to each other by stacking faults, typically by fractions of a minute of arc.

The transformation of vaterite into calcite may be poisoned also by substitutional impurities, such as $\mathrm{Mn}^{2+}$ (Nassrallah-Aboukais et al., 1998a), $\mathrm{Cu}^{2+}$ (Nassrallah-
Aboukais et al., 1998b) and $\mathrm{Mg}^{2+}$ (Kitamura, 2001; Nishino et al., 2009), but is hastened by $\mathrm{Cd}^{2+}$ and $\mathrm{Pb}^{2+}$ (Brecevic et al., 1996; Noethig Laslo and Brecevic, 1999, 2000). This explanation apparently does not apply to biogenic carbonates, because the calcite crystals produced by tobacco generally hold more trace metals than vaterite (Table 1), and vaterite has more cadmium.

\subsection{Health care and environmental implications}

Tobacco smoking is one of the main exposure routes for humans to heavy metals and particularly to $\mathrm{Cd}$ (Lugon-Moulin et al., 2004; Stephens et al., 2005). Stim- 
ulating the excretion of Cd-containing grains with a $\mathrm{Ca}$ supplement during tobacco growth and enforcing their removal during cigarette manufacturing could help decrease $\mathrm{Cd}$ poisoning. Tobacco is also a good candidate for the phytoextraction of metals from contaminated solid matrices due to its high biomass, fast growth, and ease of harvesting (Keller et al., 2003). Choi et al. (2001) estimated that a tobacco plant exposed in vitro for three weeks to $0.2 \mathrm{mM} \mathrm{Cd}$ and $30 \mathrm{mM} \mathrm{Ca}$ can excrete $4.2 \mu \mathrm{g}$ of $\mathrm{Cd}$. When plants were exposed for one month, the total $\mathrm{Cd}$ content in unwashed leaves with trichomes was $6.3 \mu \mathrm{g}$ per plant, which suggests that the elimination of grains by trichomes is an effective mechanism of $\mathrm{Cd}$ detoxification (Choi and Harada, 2005). However, the application of this process to phytoextraction requires harvesting grains from the plants, otherwise their fall on the ground and subsequent acidic dissolution would release cadmium.

\section{ACKNOWLEDGMENTS}

The manuscript benefited from comments and suggestions by two anonymous reviewers. We acknowledge the ALS (Berkeley, California) and the ESRF (Grenoble, France) for the provision of beamtime. The operations of the Advanced Light Source at Lawrence Berkeley National Laboratory are supported by the Director, Office of Science, Office of Basic Energy Sciences, US Department of Energy under contract number DE-AC0205CH11231. Emiko Harada is the recipient of fellowships from the BioGreen 21 program, the International Human Frontier Science Program Organization, and the Alexander von Humboldt Foundation.

\section{REFERENCES}

Arnott H. J. and Pautard F. G. E. (1970) Calcification in plants. In Biological Calcification: Cellular and Molecular Aspects (ed. H. Schraer). Appleton Century Crofts, New-York, pp. 375-446.

Borodin V. L., Lyutin V. I., Ilyukhin V. V. and Belov N. V. (1979) Isomorphous calcite-octavite series. Sov. Phys. Dokl. 24, 226.

Bouropoulos N., Weiner S. and Addadi L. (2001) Calcium oxalate crystals in tomato and tobacco plants: morphology and in vitro interactions of crystal-associated macromolecules. Chem. Eur. J. 7, 1881-1888.

Braissant O., Cailleau G., Dupraz C. and Verrecchia E. P. (2003) Bacterially induced mineralization of calcium carbonate in terrestrial environments: the role of exopolysaccharides and amino acids. J. Sediment. Res. 73, 485-490.

Brecevic L., Nothig-Laslo V., Kralj D. and Popovic S. (1996) Effect of divalent cations on the formation and structure of calcium carbonate polymorphs. J. Chem. Soc. Faraday Trans. 6, 10171022.

Bringezu K., Lichtenberger O., Leopold I. and Neumann D. (1999) Heavy metal tolerance of Silene vulgaris. J. Plant Physiol. 154, 536-546.

Bromiley F. A., Boffa Ballaran T., Langenhorst F. and Seifert F. (2007) Order and miscibility in the otavite-magnesite solid solution. Am. Mineral. 92, 829-836.

Callow J. A., Hallahan D. L. and Gray J. C. (2000) Advances in Botanical Research: Plant Trichomes. Academic Press, San Diego.

Chada V. G. R., Hausner D. B., Strongin D. R., Rouff A. A. and Reeder R. J. (2005) Divalent Cd and Pb uptake on calcite $\{101$ -
4\} cleavage faces: an XPS and AFM study. J. Colloid Interface Sci. 288, 350-360.

Choi Y.-E. and Harada E. (2005) Roles of calcium and cadmium on Cd-containing intra- and extracellular formation of $\mathrm{Ca}$ crystals in tobacco. J. Plant Biol. 48, 113-119.

Choi Y.-E., Harada E., Wada M., Tsuboi H., Morita Y., Kusano T. and Sano H. (2001) Detoxification of cadmium in tobacco plants: formation and active excretion of crystals containing cadmium and calcium through trichomes. Planta 213, 45-50.

Choi Y.-E., Harada E., Kim G. H., Yoon E. S. and Sano H. (2004) Distribution of elements on tobacco trichomes and leaves under cadmium and sodium stresses. J. Plant Biol. 47, 75-82.

Clemens S. (2006) Toxic metal accumulation, responses to exposure and mechanisms of tolerance in plants. Biochimie 88, 17071719.

Colfen H. and Antonietti M. (1998) Crystal design of calcium carbonate microparticles using double-hydrophilic block copolymers. Langmuir 14, 582-589.

Dalas E., Klepetsanis P. and Koutsoukos P. G. (1999) Overgrowth of calcium carbonate on poly(vinyl chloride-co-vinyl acetateco-maleic acid). Langmuir 15, 8322-8327.

Dennis J. E., Xiao S.-Q., Agarwal M., Fink D. J., Heuer A. H. and Caplan A. I. (1996) Microstructure of matrix and mineral components of eggshells from white leghorn chickens (Gallus gallus). J. Morphol. 228, 287-306.

Effenberger H., Mereiter K. and Zemann J. (1981) Crystal structure refinements of magnesite, rhodochrosite, siderite, smithsonite, and dolomite, with discussion of some aspects of the stereochemistry of calcite type carbonates. Z. Kristallogr. 156, 233243.

Elzinga E. J. and Reeder R. J. (2002) X-ray absorption spectroscopy study of $\mathrm{Cu}^{2+}$ and $\mathrm{Zn}^{2+}$ adsorption complexes at the calcite surface: implications for site-specific metal incorporation preferences during calcite crystal growth. Geochim. Cosmochim. Acta 66, 3943-3954.

Evain M. (1992) U-Fit Program. Institut des Matériaux de Nantes, France.

Falini G., Fermani S., Vanzo S., Miletic M. and Zaffino G. (2005) Influence on the formation of aragonite or vaterite by otolith macromolecules. Eur. J. Inorg. Chem. 1, 162-167.

Franceschi V. R. and Homer H. T. J. (1980) Calcium oxalate crystals in plants. Bot. Rev. 46, 361-427.

Franceschi V. R. and Nakata P. A. (2005) Calcium oxalate in plants: formation and function. Annu. Rev. Plant Biol. 56, 4171.

Giralt S., Julia R. and Klerkx J. (2001) Microbial biscuits of vaterite in Lake Issyk-Kul (Republic of Kyrgyzstan). $J$. Sediment. Res. 71, 430-435.

Hammersley A. P., Svensson S. O., Hanfland M., Fitch A. N. and Hausermann D. (1996) Two-dimensional detector software: from real detector to idealised image or two-theta scan. High Press. Res. 14, 235-248.

Hasse B., Ehrenberg H., Marxen J. C., Becker W. and Epple M. (2000) Calcium carbonate modifications in the mineralized shell of the freshwater snail Biomphalaria glabrata. Chem. Eur. J. 6, 3679-3685.

Isaure M. P., Fayard B., Sarret G., Pairis S. and Bourguignon J. (2006) Localization and chemical forms of cadmium in plant samples by combining analytical electron microscopy and Xray spectromicroscopy. Spectrochim. Acta B 61, 1242-1252.

Iwasaki K. and Matsumura A. (1999) Effect of silicon on alleviation of manganese toxicity in pumpkin (Cucurbita moschata Duch cv. Shintosa). Soil Sci. Plant Nutr. 45, 909-920.

Kanakis J. and Dalas E. (2000) Crystallization of vaterite on fibrin. J. Cryst. Growth 219, 277-282. 
Keller C., Hammer D., Kayser A., Richner W., Brodbeck M. and Sennhauser M. (2003) Root development and heavy metal phytoextraction efficiency: comparison of different plant species in the field. Plant Soil 249, 67-81.

Kirpichtchikova T. A., Manceau A., Spadini L., Panfili F., Marcus M. A. and Jacquet T. (2006) Speciation and solubility of heavy metals in contaminated soil using X-ray microfluorescence, EXAFS spectroscopy, chemical extraction, and thermodynamic modeling. Geochim. Cosmochim. Acta 70, 2163-2190.

Kitamura M. (2001) Crystallization and transformation mechanism of calcium carbonate polymorphs and the effect of magnesium ion. J. Colloid Interface Sci. 236, 318-327.

Kralj D., Brecevic L. and Kontrec J. (1997) Vaterite growth and dissolution in aqueous solution. III. Kinetics of transformation. J. Cryst. Growth 177, 248-257.

Krämer U., Grime G. W., Smith J. A. C., Hawes C. R. and Baker A. J. M. (1997) Micro-PIXE as a technique for studying nickel localization in leaves of the hyperaccumulator plant Alyssum lesbiacum. Nucl. Instrum. Methods Phys. Res. B 130, 346-350.

Küpper H., Lombi E., Zhao F. J. and McGrath S. P. (2000) Cellular compartmentation of cadmium and zinc in relation to other elements in the hyperaccumulator Arabidopsis halleri. Planta 272, 75-84.

Lakshminarayanan R., Chi Jin E. O., Loh X. J., Kini R. M. and Valiyaveettil S. (2005) Purification and characterization of a vaterite-inducing peptide, pelovaterin, from the eggshells of Pelodiscus sinensis (Chinese soft-shelled turtle). Biomacromolecules 6, 1429-1437.

Lavid N., Barkay Z. and Tel-Or E. (2001) Accumulation of heavy metals in epidermal glands of the waterlily (Nymphaeaceae). Planta 212, 313-322.

Lefèvre I., Marchal G., Meerts P., Correal E. and Lutts S. (2009) Chloride salinity reduces cadmium accumulation by the Mediterranean halophyte species Atriplex halimus L. Environ. Exp. Bot. 65, 142-152.

Lenaz D., Miletic M., Pizzul E., Vanzo S. and Adami G. (2006) Mineralogy and geochemistry of otoliths in freshwater fish from Northern Italy. Eur. J. Mineral. 18, 143-148.

Lowenstam H. A. (1981) Minerals formed by organisms. Science 211, 1126-1131.

Lowenstam H. A. and Abbott D. P. (1975) Vaterite: a mineralization product of the hard tissues of a marine organism (Ascidiacea). Science 188, 363-365.

Lowenstam H. A. and Weiner S. (1989) On Biomineralization. Oxford University Press, New-York.

Lucas D. and Andrews J. E. (1996) A re-examination of reported lacustrine vaterite formation in Holkham Lake, Norfolk, U.K. J. Sediment. Res. 66, 474-476.

Lugon-Moulin N., Zhang M., Gadani F., Rossi L., Koller D., Krauss M. and Wagner G. J. (2004) Critical review of the science and options for reducing cadmium in tobacco (Nicotiana tabacum L.) and other plants. Adv. Agron. 83, 111-180.

MacFarlane G. R. and Burchett M. D. (1999) Zinc distribution and excretion in the leaves of the grey mangrove, Avicennia marina (Forsk.). Vierh. Envir. Exp. Bot. 41, 167-175.

Malinowski E. R. (1977) Determination of the number of factors and the experimental error in a data matrix. Anal. Chem. 49, 612617.

Malinowski E. R. (1978) Theory of error for target factor analysis with applications to mass spectrometry and nuclear magnetic resonance spectrometry. Anal. Chim. Acta 103, 359-363.

Malkaj P. and Dalas E. (2004) Calcium carbonate crystallization in the presence of aspartic acid. Cryst. Growth Des. 4, 721-723.

Manceau A. and Matynia A. (2010) The nature of $\mathrm{Cu}$ bonding to natural organic matter. Geochim. Cosmochim. Acta 70, 25562580 .
Manceau A., Marcus M. A. and Tamura N. (2002) Quantitative speciation of heavy metals in soils and sediments by synchrotron X-ray techniques. In Applications of synchrotron radiation in low-temperature geochemistry and environmental science (eds. P. Fenter, M. Rivers, N. Sturchio and S. Sutton), pp. 341-428. Reviews in Mineralogy and Geochemistry. Mineralogical Society of America, Washington, DC.

Mann S. (2001) Biomineralization: Principles and Concepts in Bioinorganic. Oxford University Press, New-York.

Manoli F. and Dalas E. (2001) Calcium carbonate crystallization in the presence of glutamic acid. J. Cryst. Growth 222, 293-297.

Manoli F., Kanakis J., Malkaj P. and Dalas E. (2002) The effect of aminoacids on the crystal growth of calcium carbonate. $J$. Cryst. Growth 236, 363-370.

Marcus M. A., MacDowell A. A., Celestre R., Manceau A., Miller T., Padmore H. A. and Sublett R. E. (2004) Beamline 10.3.2 at ALS: a hard X-ray microprobe for environmental and materials sciences. J. Synchrotron Radiat. 11, 239-247.

Mazen A. M. A. and El Maghraby O. M. O. (1997) Accumulation of cadmium, lead and strontium, and a role of calcium oxalate in water hyacinth tolerance. Biol. Plantarum 40, 411-417.

Meyer H. J. (1969) Struktur und fehlordnung des vaterits. $Z$. Kristallogr. 128, 183-212.

Naka K. and Chujo Y. (2001) Control of crystal nucleation and growth of calcium carbonate by synthetic substrates. Chem. Mater. 13, 3245-3259.

Naka K., Huang S.-C. and Chujo Y. (2006) Formation of stable vaterite with poly(acrylic acid) by the delayed addition method. Langmuir 22, 7760-7767.

Nakata P. A. (2003) Advances in our understanding of calcium oxalate crystal formation and function in plants. Plant Sci. 164, 901-909.

Nassrallah-Aboukais N., Boughriet A., Gengembre L. and Aboukais A. (1998a) Manganese(II)/vaterite/water systems. Spectroscopic and thermodynamic study. J. Chem. Soc. Faraday Trans. 94, 2399-2405.

Nassrallah-Aboukais N., Boughriet A., Laureyns J., Aboukais A., Fischer J. C., Langelin H. R. and Wartel M. (1998b) Transformation of vaterite into cubic calcite in the presence of copper(II) species. Chem. Mater. 10, 238-243.

Nehrke G. and Van Cappellen P. (2006) Framboidal vaterite aggregates and their transformation into calcite: a morphological study. J. Cryst. Growth 287, 528-530.

Neumann D. N., Zur Nieden U., Lichtenberger O. and Leopold I. (1995) How does Armeria maritima tolerate high heavy metal concentrations? J. Plant Physiol. 146, 704-717.

Nishino Y., Oaki Y. and Imai H. (2009) Magnesium-mediated nanocrystalline mosaics of calcite. Cryst. Growth Des. 9, 223226.

Nitta I., Kida A., Fujibayashi Y., Katayama H. and Sugimura Y. (2006) Calcium carbonate deposition in a cell wall sac formed in mulberry idioblasts. Protoplasma 228, 201-208.

Noethig Laslo V. and Brecevic L. (1999) An EPR study of $\mathrm{Cd}^{2+}$ incorporation in vaterite. Phys. Chem. Chem. Phys. 1, 36973700 .

Noethig Laslo V. and Brecevic L. (2000) An EPR study of primary paramagnetic centres in $\mathrm{Cd}^{2+}$-doped vaterite. Phys. Chem. Chem. Phys. 2, 5328-5332.

Ogino T., Suzuki T. and Sawada K. (1987) The formation and transformation mechanism of calcium carbonate in water. Geochim. Cosmochim. Acta 51, 2757-2767.

Palchik N. A. and Moroz T. N. (2005) Polymorph modifications of calcium carbonate in gallstones. J. Cryst. Growth 283, 450-456.

Panfili F., Manceau A., Sarret G., Spadini L., Kirpichtchikova T., Bert V., Laboudigue A., Marcus M. A., Ahamdach N. and Libert M. F. (2005) The effect of phytostabilization on $\mathrm{Zn}$ 
speciation in a dredged contaminated sediment using scanning electron microscopy, X-ray fluorescence, EXAFS spectroscopy, and principal components analysis. Geochim. Cosmochim. Acta 69, 2265-2284.

Paquette J. and Reeder R. J. (1995) Relationship between surface structure, growth mechanism, and trace element incorporation in calcite. Geochim. Cosmochim. Acta 59, 735-749.

Pickering I. J., Prince R. C., George G. N., Rauser W. E., Wickramasinghe W. A., Watson A. A., Dameron C. T., Dance I. G., Fairlie D. P. and Salt D. E. (1999) X-ray absorption spectroscopy of cadmium phytochelatin and model systems. Biochim. Biophys. Acta 1429, 351-364.

Pokroy B., Fitch A. N., Marin F., Kapon M., Adir N. and Zolotoyabko E. (2006) Anisotropic lattice distortions in biogenic calcite induced by intra-crystalline organic molecules. J. Struct. Biol. 155, 96-103.

Qiao L. and Feng Q. L. (2007) Study on twin stacking faults in vaterite tablets of freshwater lacklustre pearls. J. Cryst. Growth 304, 253-256.

Qiao L., Feng Q. L. and Liu Y. (2008) A novel bio-vaterite in freshwater pearls with high thermal stability and low dissolubility. Mater. Lett. 62, 1793-1796.

Rautaray D., Ahmad A. and Sastry M. (2004) Biological synthesis of metal carbonate minerals using fungi and actinomycetes. $J$. Mater. Chem. 14, 2333-2340.

Rautaray D., Sanyal A., Bharde A., Ahmad A. and Sastry M. (2005) Biological synthesis of stable vaterite crystals by the reaction of calcium ions with germinating chickpea seeds. Cryst. Growth Des. 5, 399-402.

Ravel B. and Newville M. (2005) ATHENA, ARTEMis, hePhaestus: data analysis for X-ray absorption spectroscopy using IFEFFIT. J. Synchrotron Radiat. 12, 537-541.

Reeder R. J. (1983) Crystal chemistry of the rhombohedral carbonates. In Carbonates: mineralogy and chemistry (ed. R. J. Reeder), pp. 1-47. Reviews in Mineralogy and Geochemistry. Mineralogical Society of America, Washington, DC.

Reeder R. J. (1996) Interaction of divalent cobalt, zinc, cadmium, and barium with the calcite surface during layer growth. Geochim. Cosmochim. Acta 60, 1543-1552.

Reeder R. J. and Wenk H. R. (1983) Structure refinements of some thermally disordered dolomites. Am. Mineral. 68, 769-776.

Ressler T., Wong J., Roos J. and Smith I. L. (2000) Quantitative speciation of Mn-bearing particulates emitted from autos burning (methylcyclopentadienyl) manganese tricarbonyladded gasolines using XANES spectroscopy. Environ. Sci. Technol. 34, 950-958.

Rieger J., Frechen T., Cox G., Heckmann W., Schmidt C. and Thieme J. (2007) Precursor structures in the crystallization/ precipitation processes of $\mathrm{CaCO}_{3}$ and control of particle formation by polyelectrolytes. Faraday Discuss. 136, 265-277.

Rodriguez-Navarro C., Jimenez-Lopez C., Rodriguez-Navarro A., Gonzalez-Munoz M. T. and Rodriguez-Gallego M. (2007) Bacterially mediated mineralization of vaterite. Geochim. Cosmochim. Acta 71, 1197-1213.

Rowlands D. L. G. and Webster R. K. (1971) Precipitation of vaterite in lake water. Nat. Phys. Sci. 229, 158-159.

Salt D. E., Prince R. C., Pickering I. J. and Raskin I. (1995) Mechanisms of cadmium mobility and accumulation in Indian mustard. Plant Physiol. 109, 1427-1433.

Sarret G., Saumitou-Laprade P., Bert V., Proux O., Hazemann J.L., Traverse A., Marcus M. A. and Manceau A. (2002) Forms of zinc accumulated in the hyperaccumulator Arabidopsis halleri. Plant Physiol. 130, 1815-1826.

Sarret G., Balesdent J., Bouziri L., Garnier J. M., Marcus M. A., Geoffroy N., Panfili F. and Manceau A. (2004) Zn speciation in the organic horizon of a contaminated soil by micro X-ray fluorescence, micro and powder EXAFS spectroscopy and isotopic dilution. Environ. Sci. Technol. 38, 2792-2801.

Sarret G., Harada E., Choi Y.-E., Isaure M. P., Geoffroy N., Fakra S., Marcus M. A., Birschwilks M., Clemens S. and Manceau A. (2006) Trichomes of tobacco excrete zinc as zinc-substituted calcium carbonate and other zinc-containing compounds. Plant Physiol. 141, 1021-1034.

Sarret G., Isaure M. P., Marcus M. A., Harada E., Choi Y.-E., Pairis S., Fakra S. and Manceau A. (2007) Chemical forms of calcium in $\mathrm{Ca}, \mathrm{Zn}$ - and $\mathrm{Ca}, \mathrm{Cd}$-containing grains excreted by tobacco trichomes. Can. J. Chem. 85, 738-746.

Sarret G., Willems G., Isaure M. P., Marcus M. A., Fakra S. C., Frérot H., Pairis S., Geoffroy N., Manceau A. and SaumitouLaprade P. (2009) Zinc distribution and speciation in Arabidopsis halleri $\times$ Arabidopsis lyrata progenies presenting various zinc accumulation capacities. New Phytol. 184, 581-595.

Schilmiller A. L., Last R. L. and Pichersky E. (2008) Harnessing plant trichome biochemistry for the production of useful compounds. Plant J. 54, 702-711.

Setoguchi H., Okazaki M. and Suga S. (1989) Calcification in higher plants with special reference to cystoliths. In Origin, Evolution, and Modern Aspects of Biomineralization in Plants and Animals (ed. R. Crick). Plenum Press, New York, pp. 409418.

Shannon R. D. (1976) Revised effective ionic radius and systematic studies of interatomic distances in halides and chalcogenides. Acta Crystallogr. A 32, 751-767.

Shepherd R. W., Bass W. T., Houtz R. L. and Wagner G. J. (2005) Phylloplanins of tobacco are defensive proteins deployed on aerial surfaces by short glandular trichomes. Plant Cell 17, 1851-1861.

Stephens W. E., Calder A. and Newton J. (2005) Source and health implications of high toxic metal concentrations in illicit tobacco products. Environ. Sci. Technol. 39, 479-488.

Van Damme A., Degryse F., Smolders E., Sarret G., Dewitt J., Swennen R. and Manceau A. (2010) Zinc speciation in mining and smelter contaminated overbank sediments by EXAFS spectroscopy. Geochim. Cosmochim. Acta 74, 3707-3720.

Vecht A. and Ireland T. G. (2000) The role of vaterite and aragonite in the formation of pseudo-biogenic carbonate structures: implications for Martian exobiology. Geochim. Cosmochim. Acta 64, 2719-2725.

Wagner G. J., Wang E. and Shepherd R. W. (2004) New approaches for studying and exploiting an old protuberance, the plant trichome. Ann. Bot. 93, 3-11.

Webb M. A. (1999) Cell-mediated crystallization of calcium oxalate in plants. Plant Cell 11, 751-761.

Weiner S. and Dove P. M. (2003) An overview of biomineralization processes and the problem of the vital effect. In Biomineralization (eds. P. M. Dove, J. J. De Yoreo and S. Weiner), pp. 1-29. Reviews in Mineralogy and Geochemistry. Mineralogical Society of America, Washington, DC.

West A. R. (1984) Solid State Chemistry and its Applications. Wiley, New-York.

Xie A. J., Shen Y. H., Zhang C. Y., Yuan Z. W., Zhu X. M. and Yang Y. M. (2005) Crystal growth of calcium carbonate with various morphologies in different amino acid systems. J. Cryst. Growth 285, 436-443.

Zhao F. J., Lombi E., Breedon T. and McGrath S. P. (2000) Zinc hyperaccumulation and cellular distribution in Arabidopsis halleri. Plant Cell Environ. 23, 507-514.

Zolotoyabko E. and Pokroy B. (2007) Biomineralization of calcium carbonate: structural aspects. CrystEngComm 9, 1156-1161. 


\section{DISCLAIMER}

This document was prepared as an account of work sponsored by the United States Government. While this document is believed to contain correct information, neither the United States Government nor any agency thereof, nor The Regents of the University of California, nor any of their employees, makes any warranty, express or implied, or assumes any legal responsibility for the accuracy, completeness, or usefulness of any information, apparatus, product, or process disclosed, or represents that its use would not infringe privately owned rights. Reference herein to any specific commercial product, process, or service by its trade name, trademark, manufacturer, or otherwise, does not necessarily constitute or imply its endorsement, recommendation, or favoring by the United States Government or any agency thereof, or The Regents of the University of California. The views and opinions of authors expressed herein do not necessarily state or reflect those of the United States Government or any agency thereof or The Regents of the University of California. Ernest Orlando Lawrence Berkeley National Laboratory is an equal opportunity employer. 